\title{
Eğitsel Oyunların Öğrencilerin Değer Kazanımlarına Etkisi: Bir Durum Çalışması
}

\section{The Effect of Educational Games on Students' Acquisition of Value: A Case Study}

\author{
Gökhan IZGAR, Sorumlu Yazar, Dr. Öğr. Üyesi. \\ Necmettin Erbakan Üniversitesi, Ereğli Eğitim Fakültesi, Konya/Türkiye. \\ g.izgar@hotmail.com \\ https://orcid.org/0000-0002-6835-9701
}

ISSN: 1303-880X

e-ISSN: 2667-7504

http://ded.dem.org.tr

Makale Türü / Article Type:

Araştırma Makalesi / Research Article

Geliş Tarihi / Received Date: 13.05.2020

Kabul Tarihi / Accepted Date: 09.09. 2020

Yayın Tarihi / Published Date: 25.12.2020

Tr/En: $\operatorname{Tr}$

Intihal / Plagiarism: Bu makale, en az iki hakem tarafindan incelendi ve intihal içermediği teyit edildi. / This article has been reviewed by at least two referees and scanned via a plagiarism software.
Attf/Citation: Izgar, G. (2020). Eğitsel oyunların öğrencilerin değer kazanımlarına etkisi: Bir durum çalışması. Değerler Ĕgitimi Dergisi, 18 (40), s.207-241. https://doi.org/10.34234/ded.736639 
Öz: $\mathrm{Bu}$ araştırmanın temel amacı ilkokul öğretim programlarında yer alan adalet, dostluk, dürüstlük, sabır, sorumluluk, dayanışma, eşitlik değerleri kapsamında tasarlanan ve ders kazanımları ile doğrudan ilişkilendirilen eğitsel oyunların öğrencilerin bilişsel yapılarına etkisi ve öğretmen görüşlerine göre incelenmesidir. Nitel araştırma yönteminin kullanıldığ bu araştırma durum çalışması desenine göre tasarlanmıştır. 2019-2020 eğitim öğretim yılında bir devlet ilkokulunda öğrenim gören 2-3-4. sınıflardaki öğrenciler ve sınıf öğretmenleri bu araştırmanın çalışma grubunu oluşturmaktadır. Araştırmada veri toplama araçları olarak kelime ilişkilendirme testi ve yarı yapılandırılmış görüşme formu kullanılmıştır. Veriler betimsel analiz tekniğine göre çözümlenmiştir. Araştırma bulgularına göre ilkokul öğretim programlarında yer alan dürüstlük, dostluk, sorumluluk, sabır, eşitlik, dayanışma, adalet değerlerini kazandırmaya yönelik tasarlanan eğitsel oyunların öğrencilerin bilişsel yapılarını genel olarak olumlu yönde etkilediği sonucuna ulaşılmıştır. Ayrıca öğretmen görüşlerinin analizinde tasarlanan eğitsel oyunların öğretim programlarındaki kazanımlarla ilişkili olduğu, öğrencilere değer kazanma sürecinde somut yaşantı imkânı sağladığı, öğrencilerin eğitsel oyunlara katılmada istekli oldukları ve eğlenerek oynadıkları, eğitsel oyunların oynanmasında herhangi bir zorluk yaşanmadığı sonuçlarına da ulaşılmıştır. Ancak öğretmenler bazı oyunlarda küçük düzenlemelerin yapılması gerektiğini de belirtilmişlerdir.

Anahtar Kelimeler: Eğitsel oyun, Oyunla öğretim, Değerler eğitimi, Durum çalışması.

\section{$\&$}

Abstract: The main purpose of this research is to examine the effects of educational games, designed according to the values of justice, friendship, honesty, patience, helpfulness, solidarity and equality, on students' cognitive structures and teacher opinions. This research is a case study in which qualitative research method is used. Students and teachers in the $2 \mathrm{nd}$, 3rd and 4th grades in a public primary school in the 2019-2020 academic year constitute the working group of this research. In the research, word association test and semi-structured interview form were used as data collection tools. The data were analyzed using descriptive analysis technique. In the research, it was concluded that educational games affect students' cognitive structures positively. According to the opinions of the teachers, educational games are related to the curriculum, they are effective in learning values, and students have fun playing with, the results suggest that there are no difficulties in playing the games. However, teachers 
also indicated that small arrangements should be made in some games.

Keywords: Educational game, Game teaching, Values education, Case study.

(The Extended Abstract is at the end of the article)

\section{Giriş}

Değerlerin kuşaktan kuşağa aktarımı eğitim aracıyla olabilmektedir. Birey belirli değerleri ilk çocukluk döneminden itibaren informal eğitim kapsamında yani aileden ve sosyal çevreden almaya başlamaktadır. İlerleyen süreç içerisinde birey, aile ve sosyal çevreden kazandığı bu değerler ile formal eğitime başka bir ifadeyle okula gelmektedir. Halstead ve Taylor'a (2000) göre formal eğitim içerisinde yer alan okulun rolü iki yönlüdür. Birincisi çocukların hâlihazırda toplumda mevcut olan bir dizi değere daha fazla maruz kalma durumu sunarak kazanmaya başladıkları değerleri geliştirmek ve desteklemektir. İkincisi ise çocukların kendi gelişmekte olan değerlerini yansıtmalarına, anlamlandırmalarına ve uygulamalarına yardımcı olmaktır. Bu noktada Milli Eğitim Bakanlığı ([MEB], 2010) değerler eğitimini, "toplumsal hayatı oluşturan, insanları birbirine bağlayan, gelişmeyi, mutluluğu ve huzuru sağlayan, risk ve tehditlerden koruyan ahlaki, insani, sosyal, manevi değerlerin tüm bireylere kazandırılması", şeklinde tanımlamaktadır. İfade edilen bu değerlerin öğrencilere kazandırılması sürecinde öğretim programları en önemli araç olarak karşımıza çıkmaktadır. Şöyle ki; Türk eğitim sistemi içerisinde değerler eğitimi adında doğrudan bir ders bulunmamakla birlikte her bir öğretim kademesi içerisinde yer alan farklı öğretim programları ile öğrencilere söz konusu değerler kazandırılmaya çal1ş1lmaktadır. Örneğin Din Kültürü ve Ahlak Bilgisi Dersi Öğretim Programında sevgi, saygı, kardeşlik, arkadaşlık, dostluk, vatan, millet, bayrak, şehitlik, gazilik gibi milli, manevi ve toplumsal değerlere yer verilmektedir (MEB, 2018). Yine İnsan Hakları, Yurttaşlık ve Demokrasi Dersi Öğretim Programı'nda “'̇nsani değerleri benimseyen, hak ve özgürlüklerin kullanılabilmesi için sorumluluk üstlenen bireylerin yetiştirilmesi” (MEB, 2018) ifadesi değerler eğitimi açısından söz konusu dersin rolünü göstermektedir.

Okullarda resmi programlarda yer alan ve almayan değerleri öğrencilere kazandırmanın çeşitli yolları vardır. Telkin yoluyla öğretme, davranış değiştirme yoluyla öğretme, değerleri belirginleştirme, değer analizi, ahlaki gelişim yaklaşımları bu yollar arasında sayılabilir (Kupchenko \& Parsons, 1987). Değerler eğitiminde kullanılan bu yaklaşımların yanı sıra öğrencilere değer kazan- 
dırmada çeşitli yöntemler de kullanılmaktadır. Bu yöntemler arasında anlatım, gösteri, soru-cevap (Kaymakcan ve Meydan, 2011), problem çözme, işbirliğine dayalı öğretim, oyunla öğretim, simülasyon çalışmaları (Halstead ve Taylor, 2000), ahlaki meselelere veya ikilemlere dayalı tartışmalar (Kupchenko \& Parsons, 1987), gezi-gözlem, drama, örnek olay, proje tabanlı öğrenme (Yeşilyurt, 2019) yer almaktadır. Yine değerler eğitiminde, değer oylama, değerler sıralaması, seçim yapma, düşünce paylaşma, bitmemiş cümleler (UNESCO, 2005) gibi teknikler de kullanılmaktadır.

Değerler eğitiminde kullanılabilecek bu öğretim yöntem ve tekniklerin yanı sıra ilkokul çağındaki çocuklara değer kazandırmada eğitsel oyunlar da etkili olarak kullanılabilmektedir. Jersild'e (1979'dan akt. Tosuncuoğlu, 2013) göre oyunlar çocukların toplumla etkileşim ve bütünleşme sürecinde oldukça önemli bir araçtır. Eğitsel oyunlar çocukların kişisel gelişimlerine katkı sağladığı gibi bir düzene ve kurala uyma, topluluğun bir parçası olma gibi becerileri de kazanırlar. Çocuklar oyunlar sayesinde düşüncelerini ifade edebilirler, bireysel kabiliyetlerinin farkına varabilirler ve akranlarıla birlikte kimi zaman beraberce belirledikleri kurallara uyarak rekabet edebilirler. Halstead \& Taylor'ın da (2000) belirttiği gibi çocuklar oyun sürecinde birbirleriyle kuracakları ilişkiler yoluyla dürüstlük, saygı ve başkalarına karşı duyarlılık gibi birçok değerin de önemini öğrenebilirler.

Esasen çocukların doğal bir uğraşı alanı olan oyun fiziksel, bilişsel, duyuşsal, dilsel, ahlaki birçok gelişim alanına katkı sağlaması yönüyle çok eski tarihlerden itibaren eğitimin ilgi alanına girmiştir. Eğitimcilere göre çocuklar severek yaptığı şeyleri daha iyi öğrenmektedirler ve oyun çocukların severek yaptıkları bir etkinliktir. Bu yönüyle oyun etkili bir öğretim aracı olarak görülebilir (Gürer ve Arslan, 2017). Oyunun etkili bir öğretim aracı olabilmesi için çok iyi planlanmış olması gerekir. Çünkü çocuk oyun içerisinde kazandırılmak istenen davranış1 sergileyebilmelidir. Ancak bu sayede oyun eğitsel bir işlev görebilir. Aksi takdirde çocuk oyun içerisinde olumsuz davranışlar da kazanabilir. Dolayısıyla oyun içerisinde kazandırılmak istenen davranışın sergilenebileceği durumlar oluşturulmalıdır. Bu durumlar zihinsel, duyuşsal ve devinimsel öğrenme alanları ile ilişkilendirilmelidir. Ancak bu sayede çocuk için doğal bir aktivite olan oyunun eğitsel yönünden bahsedilebilir.

Eğitsel oyunlar öğrenme sürecinde çok önemli bir motivasyon aracıdır. Öğrencilerin sınıf ortamına uyum sağlamalarını, materyal geliştirmelerini, keşfederek öğrenmelerini sağlar. Oyun öğrenme için tasarlandığında, başarısızlık 
endişesi olmadan öğrencilerin birçok yolla yeteneklerini test etmelerine imkân tanır. Bu da öğrencilerin kendilerine olan güvenlerini arttırır (Altunay, 2004). Ayrıca oyun, öğrencilerin kendilerini ifade edebilecekleri en sade ve pratik yoldur. Bu da öğretmenin öğrencilerle iletişim kurmasını kolaylaştırır. Gelişim bir bütün olarak göz önüne alındığında oyun, çocukluk döneminin en önemli besleyici kaynaklarından birisidir. Çocuğun bütün gelişim alanlarına hitap eden oyunlar eğitsel olarak iyi organize edilebilirse öğrenme-öğretme sürecinin de temel araçlarından biri olması kaçınılmazdır (Koçyiğit, Tuğluk \& Kök, 2007).

\section{Araştırmanın Önemi}

Konu ile ilgili alan yazın incelendiğinde değerler eğitimi ve eğitsel oyunlarla ilgili araştırmalara rastlanmıştır (Altunay, 2004; Bayat, Kılıçaslan \& Şentürk, 2014; Biter \& Çalışkan, 2019; Bolat, 2018; Butler, 2013; Eliasa, 2014; Erdal, 2019; Gürer \& Arslan, 2017; Uzun \& Köse, 2017). Ancak değerler eğitimi kapsamında ilkokul düzeyinde öğretim programları ile doğrudan ilişkilendirilmiş ve ders etkinliklerine dayalı ek faaliyet olarak tasarlanmış eğitsel oyunların etkilerini ortaya çıkarmaya yönelik araştırmalara da ihtiyaç duyulmaktadır.

Diğer taraftan Dündar ve Hareket'in (2016) “değerler eğitimi araştırmalarında yönelimler" konulu alan yazını incelediği araştırmasında dikkat çekici sonuçlara ulaşılmıştır. Araştırmada ulusal düzeyde alan yazın ile doğrudan ilişkili olan "Değerler Eğitimi Dergisinde" yayımlanan makalelerin genel kategori dağılımı incelenmiştir. Araştırma bulgularına göre değerler eğitimi konusunda alan yazın çalışmaları ve betimsel çalışmaların ağırlıklı olarak $(\% 97,5)$ yer aldığ 1 görülmektedir. Ancak değerler eğitiminde deneysel çalışmalara ve diğer kategorilerde yer alan yayınlara çok az $(\% 2,5)$ yer verildiği bulgulanmıştır. Araştırma sonucunda değerlerin öğretimi konusunda deneysel ve öğretim ortamlarından kesitlerin sunulduğu örnek çalışmalara ihtiyaç duyulduğu belirtilmektedir. Yapılan çalışmalarda örneklem düzeylerinin daha çok yetişkin gruplar üzerine gerçekleştirildiği dolayısıyla değer öğretimi yaklaşımlarının etkililiğini görmek adına daha küçük yaş grupları ile çalışmaların yapılmasının önerildiği de görülmektedir.

Ayrıca ilkokul öğretim programları incelendiğinde programlarda belirlenen değerlerin ağırlıklı olarak dersler içerisinde yer alan çeşitli etkinlik ve faaliyetler ile öğrencilere kazandırılmaya çalışıldığı görülmektedir. Örneğin İnsan Hakları, Yurttaşlık ve Demokrasi Dersi öğretim programını ve ders kitabını inceleyen Izgar (2017), araştırmasında ders kitaplarında okuma metinleri, okuma metin- 
lerine dayalı sorular, ev ödevleri, gözlemler, tartışmalar gibi daha çok bilişsel öğrenmeler üzerine tasarlanmış etkinliklerin yer aldığı sonucuna ulaşmıştır. Bu noktada değeri özümse, davranış haline getirebilme, günlük hayatta kullanabilme gibi üst düzey becerilerin kazanımında bilişsel öğrenmelere yönelik ders içi etkinlikleri destekleyecek ek faaliyetler de göz önünde bulundurulmalıdır.

Yukarıda anlatılanların ışığında değerler eğitimi alanında küçük yaş grupları üzerine yapılacak öğretim ortamlarından kesitlerin sunulacağı örnek çalışmalara ihtiyaç duyulduğu görülmektedir. Yine ilkokul öğrencilerine değer kazandırma sürecinde okullarda yapılan ders içi faaliyetleri destekleyen ve ders kazanımları ile ilişkilendirilen etkinliklere de ihtiyaç duyulmaktadır. Ayrıca bu etkinliklerin değeri özümse, davranış haline getirebilme, günlük hayatta kullanabilme gibi üst düzey becerileri kazandırabilecek, yaparak-yaşayarak öğrenmeyi sağlayabilecek nitelikte olaması beklenmektedir. Dolayısıyla bu araştırmada tasarlanan eğitsel oyunlar söz konusu ihtiyaçlar göz önüne alınarak geliştirilmiş ve ilkokul öğrencilerinin değer kazanımları üzerine etkisi incelenmiştir.

\section{Araştırmanın Kapsamı}

İlkokul Hayat Bilgisi, Sosyal Bilgiler, Din Kültürü ve Ahlak Bilgisi, Beden Eğitimi ve Oyun, İnsan Hakları Yurttaşlık ve Demokrasi, Türkçe, Matematik, Müzik, Görsel Sanatlar, Trafik Güvenliği derslerinin öğretim programları (MEB, 2018) incelendiğinde öğrencilere kazandırılacak kök değerler belirlenmiştir ve bu kök değerler söz konusu programların tamamında yer almaktadır. Bu kök değerler şunlardır: Adalet, dostluk, dürüstlük, öz denetim, sabır, saygı, sevgi, sorumluluk, vatanseverlik, yardımseverlik. Ayrıca bu kök değerlere ek olarak Sosyal Bilgiler, Trafik Güvenliği, İnsan Hakları Yurttaşlık ve Demokrasi derslerinin öğretim programlarında (MEB, 2018) aile birliğine önem verme, özgürlük, eşitlik, dayanışma, güven, paylaşma, özgürlük, doğal çevreye duyarlılık değerlerine de yer verildiği görülmektedir. Yukarıda sözü edilen kök değerlerden dürüstlük, dostluk, sorumluluk, sabır, dayanışma, adalet değerleri ve adalet değeri ile ilişkili olan eşitlik değeri adı geçen derslerin tamamında yer alması nedeniyle araştırma kapsamında ele alınmıştır.

\section{Araştırmanın Amaci}

$\mathrm{Bu}$ araştırmanın temel amacı ilkokul Hayat Bilgisi, Sosyal Bilgiler, Din Kültürü ve Ahlak Bilgisi, Beden Eğitimi ve Oyun, İnsan Hakları Yurttaşlık ve Demok- 
rasi, Türkçe, Matematik, Müzik, Görsel Sanatlar, Trafik Güvenliği derslerinin öğretim programlarında yer alan dürüstlük, dostluk, sorumluluk, sabır, eşitlik, dayanışma, adalet değerleri kapsamında tasarlanan ve ders kazanımları ile ilişkilendirilen eğitsel oyunların öğrencilerin bilişsel yapılarına etkisi ve öğretmen görüşlerine göre incelenmesidir.

\section{Problem Gümlesi}

İlkokul öğretim programlarında yer alan dürüstlük, dostluk, sorumluluk, sabır, eşitlik, dayanışma, adalet değerleri kapsamında tasarlanan ve ders kazanımları ile ilişkilendirilen eğitsel oyunların öğrencilerin bilişsel yapılarına etkisi var mıdır?

\section{Alt Problemler}

Ana problem kapsamında aşağıdaki sorulara yanıt aranmıştır.

1. Eğitsel oyunların öğrencilerin dürüstlük değeri ile ilgili bilişsel yaplarına etkisi var midır?

2. Eğitsel oyunların öğrencilerin dostluk değeri ile ilgili bilişsel yaplarına etkisi var midir?

3. Eğitsel oyunların öğrencilerin sorumluluk değeri ile ilgili bilişsel yaplarına etkisi var midır?

4. Eğitsel oyunların öğrencilerin sabır değeri ile ilgili bilişsel yaplarına etkisi var midır?

5. Eğitsel oyunların öğrencilerin eşitlik değeri ile ilgili bilişsel yaplarına etkisi var midir?

6. Eğitsel oyunların öğrencilerin dayanışma değeri ile ilgili bilişsel yaplarına etkisi var midır?

7. Eğitsel oyunların öğrencilerin adalet değeri ile ilgili bilişsel yaplarına etkisi var midir?

8. Eğitsel oyunların öğrenciler üzerindeki etkisine yönelik öğretmen görüşleri nelerdir?

9. Eğitsel oyunların ilköğretim programlarında yer alan derslerin kazanımları ile ilişkisine yönelik öğretmen görüşleri nelerdir?

10. Değerler eğitiminde eğitsel oyunlara yer verilip verilmemesine yönelik öğretmen görüşleri nelerdir? 


\section{Yöntem}

\section{Etik Kurul Onayı ve Araştırma İzni}

$\mathrm{Bu}$ araştırmada etik sorun oluşturabilecek sorular/maddeler, süreçler ya da unsurlar bulunmadığına dair Bartın Üniversitesi Sosyal ve Beşeri Bilimleri Etik Kurulundan 18.03.2020 tarih, 10 say1 ve 2020-SBB-0033 numaral1 "Etik Kurulu Onay Belgesi" alınmıştır.

$\mathrm{Bu}$ araştırmanın yapılabilmesi için Konya Valiliği İl Milli Eğitim Müdürlüğünden 21.11.2019 tarih ve 83688308-605.01-E.23034471 sayılı yazısı ile araştırma izni alınmıştır.

\section{Araştırma Deseni}

Nitel araştırma yönteminin kullanıldığ 1 bu araştırma durum çalışması desenine göre tasarlanmıştır. Yıldırım ve Şimşek’e (2005) göre nitel durum çalışmalarında, bir duruma ilişkin etkenler bütüncül bir yaklaşımla araştırılır ve ilgili durumu nasıl etkiledikleri ve ilgili durumdan nasıl etkilendikleri incelenir. Durum çalışması desenlerinden bütüncül tek durum desenlerinde ise tek bir analiz birimi yani bir birey, bir kurum, bir program vb. vardır. Bu araştırmada "bütüncül tek durum" deseni temel alınmıştır ve "bütüncül tek durum” adalet, dostluk, dürüstlük, sabır, sorumluluk, dayanışma, eşitlik değerleri üzerine tasarlanan ve ders kazanımları ile ilişkilendirilen eğitsel oyunlardır. Dolayısıyla bu araştırmada tasarlanmış olan eğitsel oyunların öğrencilerin değer kazanımlarına etkisi incelenmiştir.

\section{Çalışma Grubu}

Çalışma grubunu oluşturacak okul ve sınıfın seçiminde araştırmacının görev yaptığ1 ilçe sınırları içinde olması dikkate alındığından çalışma grubu belirlenirken amaçlı örnekleme yöntemlerinden kolay ulaşılabilir durum örneklemesi yöntemine başvurulmuştur. Yıldırım ve Şimşek’e göre (2005) bu yöntem araştırmacının yakın ve erişilmesi kolay olan bir durumu seçtiği örnekleme tekniği olup, araştırmacıya hız ve pratiklik kazandırmaktadır. Bu kapsamda 2019-2020 eğitim öğretim yılında Konya ili Ereğli ilçesinin bir devlet ilkokulunda öğrenim gören 2-3-4. sınıflarındaki öğrenciler ve sınıf öğretmenleri bu araştırmanın çalışma grubunu oluşturmaktadır. Çalışma grubuna ait demografik bilgiler tablo-1'de sunulmuştur. 
Tablo 1: Çalışma Grubuna Ait Demografik Bilgiler

\begin{tabular}{lllllll}
\hline \multirow{2}{*}{ Sınıf } & \multicolumn{2}{c}{ Öğrenci Sayıları } & \multicolumn{3}{c}{ Öğretmen Bilgileri } \\
\cline { 2 - 7 } & K & $\mathbf{E}$ & Toplam & $\mathbf{K}$ & $\mathbf{E}$ & Kıdem Yılı \\
\hline 2 & 7 & 12 & 19 & -- & 1 & 18 \\
\hline 3 & 12 & 13 & 25 & 1 & -- & 17 \\
\hline 4 & 13 & 12 & 25 & -- & 1 & 16 \\
\hline Toplam & 32 & 37 & 69 & 1 & 2 & -- \\
\hline
\end{tabular}

\section{Veri Toplama Araçları}

Araştırmada birinci veri toplama aracı olarak kelime ilişkilendirme testi kullanılmıştır. Kelime ilişkilendirme testi ile uygulama öncesi ve sonrası öğrencilerin söz konusu değerlere yönelik bilişsel yapılarının ortaya çıkartılması amaçlanmıştır. Kelime ilişkilendirme testi bireyin herhangi bir konu veya olgu hakkındaki bilişsel yapısını, bu yapıdaki kavramlar arasındaki bağları, uzun dönemli hafızasındaki kavramlar arasındaki ilişkilerin yeterli veya anlamlı olup olmadığını ortaya çıkartan alternatif ölçme değerlendirme aracıdır (Bahar, Johnstone \& Sutcliffe, 1999). Kelime ilişkilendirme testi oluşturmak için dürüstlük, dostluk, sorumluluk, sabır, eşitlik, dayanışma ve adalet değerleri seçilmiştir. Her bir değerin altına o değerle ilgili kavramların yazılabilmesi için üç adet boşluk bırakılmıştır. Öğrencilerden kendilerine verilen süre içerisinde anahtar değerle ilişkili olduğunu düşündükleri kelimeleri testteki ilgili boşluğa yazmaları istenmiştir. Kelime ilişkilendirme testinin uygulanması ile ilgili çalışmalar incelendiğinde her bir cevap kâğıdı için katılımcılara 30 saniye vermenin en uygun zaman dilimi olduğu tespit edilmiştir (Bahar \& Özatlı, 2003). Ancak öğrencilerin küçük yaşta olmaları nedeniyle bu süre 1 dakikaya uzatılmıştır. Dolayısıyla öğrencilere uygulamaya başlamadan önce kelime ilişkilendirme testi hakkında gerekli açıklamalar yapılmış ve kendilerine verilen süre zarfında uygulamanın tamamlanması sağlanmıştır.

Araştırmada ikinci veri toplama aracı olarak yarı yapılandırılmış görüşme formu kullanılmıştır. Yıldırım ve Şimşek'e göre (2005) görüşme esnasında irdelenecek sorular veya konular listesi görüşme formunda yer alır. Bu yöntem benzer konuları incelemek amacıyla değişik insanlardan aynı tür bilgilerin toplanabilmesine imkân tanır. Buradan hareketle hazırlanan görüşme formu arac1lığıyla eğitsel oyunların öğrenciler üzerindeki etkileri ile söz konusu oyunlar hakkındaki öğretmen görüşlerinin ortaya çıkarılması amaçlanmıştır. Görüşme formunun hazırlanmasında ilk olarak alanyazın taranmış daha sonra alanla ilgili çalışmaları olan iki öğretim üyesinin görüşlerine başvurularak beş sorudan 
oluşan taslak form oluşturulmuştur. Dil ve anlam açısından Türkçe alan uzmanının görüşüne başvurularak gerekli düzeltmeler yapılmıştır. Çalışma grubunda olmayan iki öğretmene ön uygulaması yapılmıştır. Yapılan kontrollerden sonra uzmanların öneri ve eleştirileri dikkate alınarak benzer özellikleri ölçen iki sorunun çıkarılmasına karar verilmiştir. Üç açık uçlu sorudan oluşan görüşme formuna son hali verilmiştir. Bu sorular;

1- Kazandırılmak istenen değerlerle ilgili tasarlanan eğitsel oyunların öğrencileriniz üzerindeki etkileri hakkında neler düşünüyorsunuz?

2- Eğitsel oyunlar, ilköğretim programında yer alan derslerin kazanımları ile ilişsili midir?

3- Değerler eğitiminde eğitsel oyunlara yer verilmeli midir?

\section{Verilerin Analizi}

Birinci veri aracı olan kelime ilişkilendirme testinin analizinde elde edilen verileri çözümleyebilmek için her bir değerle ilişkilendirilen kelimeler tasniflenmiştir. Tasnifflenen kelimelerin ilgili değer ile ilişkili olup olmadığ miştir. İlgili değer ile ilişkili olan kelimeler analize alınmıştır. Değer ile ilişkili olan her bir kelimenin tekrarlanma sıklığı ortaya çıkartılmıştır. İlgili değerlerle ilişkilendirilen kelimelerin tekrarlanma sıklıklarını gösteren frekans tabloları hazırlanmıştır (Bahar, Johnstone \& Sutcliffe, 1999). Uygulama öncesi ve sonras1 frekans tabloları ile öğrencilerin dürüstlük, dostluk, sorumluluk, sabır, eşitlik, dayanışma ve adalet değerleri hakkındaki bilişsel yapıları ortaya çıkartılmıştır.

İkinci veri toplama aracı olan yarı yapılandırılmış görüşme formunun analizinde betimsel analiz tekniği kullanılmıştır. Yıldırım ve Şimşek'e göre (2005) betimsel analiz yaklaşımında elde edilen veriler, araştırma sorularının ortaya koyduğu kategorilere göre düzenlenebileceği gibi, görüşme ve gözlem süreçlerinde kullanılan sorular ya da boyutlar dikkate alınarak da sunulabilir. Bu yaklaşımda görüşülen ya da gözlemlenen bireylerin görüşlerini çarpıcı bir biçimde yansıtmak amacıyla doğrudan alıntılara sık sık yer verilir. Bu tür analizde amaç, elde edilen bulguları düzenlenmiş ve yorumlanmış bir biçimde okuyucuya sunmaktır. Verilerin analizinde kullanılan temalar araştırmacı tarafından hazırlanan görüşme formunda bulunan sorular 1şı̆̆ında oluşturulmuştur.

Verilerin analizinde güvenirliğin sağlanabilmesi için görüşme formundan elde edilen veriler, araştırmacı ve eğitim bilimleri alanında görevli bir öğretim üyesi tarafından ayrı ayrı kodlanarak değerlendirmiştir. Veri çözümlemesinde 
aynı kodlamanın yapıldığı durumlar görüş birliği ve farklı kodlamanın yapıldığı durumlar görüş farklılığı olarak belirlenmiştir. Görüş birliği ve görüş farklılı̆g 1 ile ilgili olarak yapılan hesaplamalar sonucunda; kodlamalar arasındaki ortalama güvenirlik oranı \% 91 olarak bulunmuştur. Miles ve Huberman'a (1994) göre güvenirlik hesaplamasının \% 70'in üzerinde çıkması araştırmanın güvenilir olarak kabul edilmesinde yeterli bir sonuçtur.

\section{Uygulama}

Araştırma süreci; eğitsel oyunların tasarlanması, uygulanması (öğrenme-öğretme durumları) ve veri toplama araçlarının toplanması olmak üzere üç aşamada gerçekleştirilmiştir.

\section{Eğitsel oyunların tasarlanması}

İlkokul öğretim programları tümüyle incelenerek 2, 3, ve 4. sınıf programlarında yer alan ortak değerlerden dürüstlük, dostluk, sorumluluk, sabır, eşitlik, dayanışma ve adalet değerleri araştırma kapsamına alınmıştır. Araştırma kapsamına alınan değerlerle ilgili kazanımlar oluşturulduktan sonra araştırmacı tarafından eğitsel oyunlar tasarlanmıştır. Tasarlanan oyunlar ilgili sınıflarda yer alan derslerin kazanımları ile ilişkilendirilmiştir. Buradaki temel amaç öğrencilerin ilgili derslerde işledikleri ders etkinliklerinin hazırlanan eğitsel oyunlarla somutlaştırılmasıdır. Dolayısıyla hem eğitsel oyunların kazanımlarını hem de ilişkilendirilen ders kazanımlarını kapsayacak şekilde oyunlar tasarlanmıştır. Öğrencilerin gelişimsel dönemleri dikkate alınarak: çocuğa görelik ilkesine; öğrencilerin yaparak-yaşayarak öğrenmesi dikkate alınarak: aktivite ilkesine; oyunların hayat ile ilişkilendirilmesi dikkate alınarak: hayata yakınlık ilkesine ve öğrencilerin bilişsel, duyuşsal, devinimsel öğrenme alanları dikkate alınarak: bütünlük ilkesine hizmet edecek şekilde oyunlar tasarlanmıştır. Ayrıca oyunların sonunda değerlendirme bölümüne yer verilerek, öğretmenlere oyun ile değerin ilişkilendirilmesinde yapılabilecekler hakkında öneriler sunulmuştur. Yine sınıfta kaynaştırma eğitimine tabi olmuş öğrenciler var ise onların özel gereksinimi göz önüne alınarak kontrollü bir şekilde oyuna katılmalarının sağlanabilmesi için uyarlamalar yapılmıştır. Yazarın (Izgar, 2020) geliştirdiği örnek bir eğitsel oyun tasarımı tablo-2'de sunulmuştur. 
Tablo 2: Örnek Bir Eğitsel Oyun Tasarımı

Oyun Adı: Arkadaşlık Panosu

Değer: Dostluk

Uygulanacak Sinıf Düzeyi: 2.3.4

Kazanımlar:

1-Sosyal hayat içinde arkadaşlığın önemli bir değer olduğunu fark eder.

2-Arkadaşlık ilişkileri kurma ile ilgili beceriler gösterir.

Ders Kazanımlarıyla İlişkilendirme: Etkinlik, ilköğretim kurumları öğretim programlarında yer alan Hayat Bilgisi, Sosyal Bilgiler, İnsan Hakları, Yurttaşlık ve Demokrasi (MEB, 2018) derslerine ait kazanımlar ile iliş̧kilendirilmiştir.

HB.2.1.8. Okulda iletişim kurarken kendini anlaşılır ve açık bir dille ifade eder.

HB.3.1.2. Davranışlarının kendisini ve arkadaşlarını nasıl etkilediğini fark eder.

HB.3.1.3. Arkadaşlarının davranışlarının kendisini nasıl etkilediğini fark eder.

HB.3.1.4. Arkadaşlık sürecinde dikkat edilmesi gereken hususları kavrar.

SB.4.1.3. Bireysel ilgi, ihtiyaç ve yeteneklerini tanır.

Y.4.3.1. İnsanların farklılıklarına saygı gösterir.

Malzemeler: Öğrenci sayısı kadar $25 \times 40 \mathrm{~cm}$. ebadında köpük. Yeteri miktarda küçük not kâğgtları, 1 kutu toplu iğne.

Öğrenme Süreci:

-Her bir öğrenci için köpükten yapılan panolar üzerine öğrencinin isimi de yazılarak sınıfın uygun yerine asilır.

-Öğrencilerden sınıf ve okul içerisinde edindikleri her bir arkadaş için küçük not kâğıtlarına arkadaşının ismini yazması istenir.

-Ayrıca bu küçük not kâğıtlarına arkadaşları ile birlikte geçirdikleri anları, paylaşımları, oyunları vb. durumları da belirtmeleri istenir.

-Yazdıkları her bir kâğıdı panolarına iğnelemeleri gerektiği belirtilir.

-Oyunun 1 ay süresince devam edeceği bildirilir.

-Bu sürenin sonunda arkadaşlık panolarında en çok ismi yazılan öğrencinin oyunu kazanacağı bildirilir.

Değerlendirme: Oyun sonunda ismi en çok yazılan birkaç öğrenciden arkadaşlık ile ilgili düşüncelerini sınıfta paylaşması istenir. Ayrıca her bir öğrenciden arkadaşı ile geçirdiği ve unutamadığı bir anısını paylaşması istenir. Öğretmen açısından değerlendirme aşamasındaki en önemli nokta panolarda hiç ismi olmayan veya diğer öğrencilere nazaran çok az ismi yer alan öğrencilerin tespitidir. Eğer bu tür öğrenciler tespit edilmiş ise bu durum sınıf içerisinde hissettirilmemeli ve bu öğrencilere has özel önlemler alınmalıdır. Örneğin eğitsel kulüp çalışmalarında, okul kutlama programlarında, serbest etkinlikler ve beden eğitimi gibi derslerde iletişimi ve arkadaşlık kurmayı sağlayacak görevler verilerek söz konusu öğrencilerin sosyalleşmeleri sağlanabilir.

Uyarlama: Eğer sınıfta kaynaştırma eğitimine tabi olmuş öğrenciler var ise onların özel gereksinimi göz önüne alınarak kontrollü bir şekilde oyuna katılmaları sağlanabilir. Örneğin görme engelli bir öğrenciye panosunu oluşturmada yardım edecek bir arkadaşı görevlendirilebilir.

Öğretmenlere Öneriler: Oyunun süresi sınıf düzeyine göre öğretmenin uygun bulacağı sınırlara çekilebilir. Uygulama süresince panoların belirli aralıklarla sınıfça beraber incelenmesinde fayda vardır. Çünkü öğrenciler, öğretmenin bu durumu önemsediğini hissederler ve arkadaşlık ilişkilerini arttırmada daha çok çaba sarf ederler. Unutulmamalıdır ki öğretmenden gelecek bir pekiştirecek ilkokul öğrencileri için çok önemli bir başarıdır. 


\section{Öğrenme-öğretme durumları}

Tasarlanan eğitsel oyunlar söz konusu değer ile ilgili ders etkinliğinden sonra uygulanmıştır. Buradaki temel amaç öğrencilerin söz konusu değer ile ilgili bilişsel öğrenmelerini gerçekleştirdikten sonra bu bilgilerin anlamlandırılabilmesi için duyuşsal ve devinimsel alan ile ilgili ilişkilendirmenin yapılabilmesidir. Nitekim tasarlanan oyunlar duygulara ve fiziksel aktivitelere hitap etmektedir. Dolayısıyla oyunlar sınıf öğretmenlerinin ders planlarına göre uygun olan zamanlarda oynatılmıştır. Eğitsel oyunlar 2019-2020 eğitim-öğretim yılının ilk döneminde 7 haftalık süre zarfında tamamlanmıştır.

\section{Verilerin toplanmasi}

Öğrencilere uygulanan her bir eğitsel oyun öncesi ve sonrası kelime ilişkilendirme testi yapılmıştır. Dolayısıyla öğrenci verileri 7 hafta süresince adım adım toplanmıştır. Eğitsel oyun uygulamaları bitiminde ise her bir öğretmen ile ayrı ayrı görüşmeler yapılarak öğretmenlere ait veriler toplanmıştır.

\section{Bulgular}

Bu bölümde öğrencilerin dürüstlük, dostluk, sorumluluk, sabır, eşitlik, dayanışma ve adalet değerlerine yönelik bilişsel yapılarını gösteren frekans tablolarına ve ilgili değerleri kazandırmaya yönelik tasarlanan eğitsel oyunların etkililiğine yönelik öğretmen görüşlerine yer verilmiştir.

\section{Eğitsel Oyunların Öğrencilerin Dürüstlük Değeri ile İlgili Bilişsel Yaplarına Etkisi Var mıdır? Sorusuna Yönelik Bulgular}

Araştırmaya katılan öğrencilerin sınıf düzeylerine göre uygulama öncesi ve sonrası dürüstlük değeri ile ilişkili bilişsel yapılarını gösteren kelimeler ve frekans değerleri tablo 3'de verilmiştir.

Tablo 3: Öğrencilerin Dürüstlük Değeri İle İlişkilendirdikleri Kelimelere Yönelik Oluşturulan Frekans Tablosu

\begin{tabular}{lllllll}
\hline & 2. Sinıf $(\mathrm{N}=17)$ & $\mathrm{f}$ & 3. Sinıf $(\mathrm{N}=22)$ & $\mathrm{f}$ & 4. Sinıf $(\mathrm{N}=23)$ & $\mathrm{f}$ \\
\hline \multirow{3}{*}{ Ön test } & Doğruyu söylemek & 4 & Doğruyu söylemek & 17 & Yalan söylememek & 10 \\
\cline { 2 - 7 } & Bir şeyi saklamamak & 1 & Yalan söylememek & 11 & Doğruluk & 8 \\
\cline { 2 - 7 } & & Adalet & 5 & Güven & 2 \\
\cline { 2 - 7 } & & & Açık sözlü olmak & 1 \\
\hline
\end{tabular}




\begin{tabular}{lllllll}
\hline Toplam & Kelime sayısı=2 & 5 & Kelime sayısı=3 & 33 & Kelime sayısı=4 & 21 \\
\hline & Doğruyu söylemek & 7 & Doğruyu söylemek & 12 & Yalan söylememek & 6 \\
\cline { 2 - 7 } & Yanlış söylememek & 8 & Yalan söylememek & 18 & Doğruluk & 3 \\
\cline { 2 - 6 } & Güvenilir & 1 & Adaletli olmak & 17 & Sözünde durmak & 3 \\
\cline { 2 - 6 } Son test & Çalmamak & 1 & Sözünü tutmak & 9 & Güven & 4 \\
\cline { 2 - 6 } & Hatayı söylemek & 1 & Hile yapmamak & 2 & Gerçek & 1 \\
\cline { 2 - 6 } & & $\begin{array}{l}\text { Başkasının eşyasını izinsiz } \\
\text { almamak }\end{array}$ & 2 & Ahlâk & 1 \\
\cline { 2 - 6 } & & & Kelime sayısı=6 & 60 & Kelime sayısı=7 & 19 \\
\hline Toplam & Kelime sayısı=5 & 18 & & & 1 \\
\hline
\end{tabular}

Tablo 3'e göre 2. sınıf düzeyindeki öğrenciler eğitsel oyun öncesi dürüstlük değeri ile ilgili olarak 2 kelime ilişkilendirirken uygulama sonrası ilişkilendirdikleri kelime sayısı 5'e çıkmış ve frekans değeri 5'ten 18'e yükselmiştir. 3. sınıf düzeyindeki öğrenciler eğitsel oyun öncesi dürüstlük değeri ile ilgili olarak 3 kelime ilişkilendirirken uygulama sonrası ilişkilendirdikleri kelime sayısı 6'ya çıkmış ve frekans değeri 33’ten 60'a yükselmiştir. 4. sınıf düzeyindeki öğrenciler eğitsel oyun öncesi dürüstlük değeri ile ilgili olarak 4 kelime ilişkilendirirken uygulama sonrası ilişkilendirdikleri kelime sayısı 7'ye çıkmış ancak frekans değeri 21'den 19'a inmiştir. Ayrıca öğrenci sayılarının birbirine yakın olmasına rağmen 3. sınıf öğrencilerinin frekans değerinin 4. sınıf öğrencilerinden daha fazla olması da dikkat çekici bir sonuçtur. Bu sonuç öğrencilerin hazırbulunuşluk düzeyleri arasındaki farklılıktan kaynaklandığı şeklinde yorumlanabilir.

\section{Eğitsel Oyunların Öğrencilerin Dostluk Değeri ile İlgili Bilişsel Yaplarına Etkisi Var mıdır? Sorusuna Yönelik Bulgular}

Araştırmaya katılan öğrencilerin sınıf düzeylerine göre uygulama öncesi ve sonrası dostluk değeri ile ilişkili bilişsel yapılarını gösteren kelimeler ve frekans değerleri tablo 4'de verilmiştir. 
Tablo 4: Öğrencilerin Dostluk Değeri İle İlişkilendirdikleri Kelimelere Yönelik Oluşturulan Frekans Tablosu

\begin{tabular}{|c|c|c|c|c|c|c|}
\hline & 2. $\operatorname{Sin} 1 f(N=15)$ & $f$ & 3. $\operatorname{Sin} 1 f(N=22)$ & $\mathrm{f}$ & 4. $\operatorname{Sin} 1 f(N=16)$ & $\mathrm{f}$ \\
\hline \multirow{9}{*}{ Ön test } & Arkadaş olmak & 9 & Arkadaş olmak & 22 & Arkadaş olmak & 14 \\
\hline & Sevmek & 4 & Paylaşmak & 12 & Sevmek & 8 \\
\hline & Güvenmek & 2 & Yardım etmek & 5 & Yardım etmek & 1 \\
\hline & Paylaşmak & 1 & Sevmek & 3 & Dayanışma & 4 \\
\hline & Sözünde durmak & 1 & Destek olmak & 3 & İyilik yapmak & 1 \\
\hline & İyi kalpli & 1 & İyilik yapmak & 2 & Sayg1 & 2 \\
\hline & Dayanışma & 1 & Dayanışma & 1 & Dürüst olmak & 1 \\
\hline & Sayg1 & 1 & & & Beraberlik & 1 \\
\hline & & & & & Anlaşmak & 1 \\
\hline Toplam & Kelime sayıs $1=8$ & 20 & Kelime sayısı $=7$ & 48 & Kelime sayısı $=9$ & 33 \\
\hline \multirow{13}{*}{ Son test } & Arkadaş olmak & 10 & Arkadaş olmak & 12 & Arkadaş olmak & 9 \\
\hline & Sevmek-sevilmek & 4 & Paylaşmak & 1 & Sevmek & 7 \\
\hline & Paylaşmak & 3 & Yardım etmek & 2 & Yardım etmek & 1 \\
\hline & Dürüst olmak & 5 & Sevmek & 9 & İyilik yapmak & 8 \\
\hline & İyi geçinmek & 2 & Destek olmak & 12 & Sayg1 & 1 \\
\hline & Yardım etmek & 1 & İyilik yapmak & 11 & Dürüst olmak & 3 \\
\hline & Yalan söylememek & 1 & Dürüst olmak & 7 & Paylaşmak & 1 \\
\hline & Sayg1 & 1 & Sayg1 & 4 & Güvenmek & 2 \\
\hline & İhanet etmemek & 1 & Yalan söylememek & 1 & Fedakârlık & 1 \\
\hline & & & Sözünde durmak & 2 & Ayrımc1lık yapmamak & 1 \\
\hline & & & Sir saklamak & 2 & Şefkat & 6 \\
\hline & & & Kavga etmemek & 1 & & \\
\hline & & & Anlayışlı & 1 & & \\
\hline Toplam & Kelime say $1 \mathrm{~s} 1=9$ & 28 & Kelime sayısı=13 & 65 & Kelime sayıs1=11 & 40 \\
\hline
\end{tabular}

Tablo 4'e göre 2. sınıf düzeyindeki öğrenciler eğitsel oyun öncesi dostluk değeri ile ilgili olarak 8 kelime ilişkilendirirken uygulama sonrası ilişkilendirdikleri kelime sayısı 9'a çıkmış ve frekans değeri 20'den 28'e yükselmiştir. 3 . sınıf düzeyindeki öğrenciler eğitsel oyun öncesi dostluk değeri ile ilgili olarak 7 kelime ilişkilendirirken uygulama sonrası ilişkilendirdikleri kelime sayısı 13'e çıkmış ve frekans değeri 48 'den 65'e yükselmiştir. 4. sınıf düzeyindeki öğrenciler eğitsel oyun öncesi dostluk değeri ile ilgili olarak 9 kelime ilişkilendirirken uygulama sonrası ilişkilendirdikleri kelime sayısı 11'e çıkmış ve frekans değeri 33'den 40'a yükselmiştir. Ayrıca 3. sınıf öğrencilerinin ilişkilendirdikleri kelime sayısı ve frekans değerinin 4. sınıf öğrencilerinden daha fazla olması dikkat çekici bir sonuçtur. Bu sonuç uygulamaya katılan öğrenci sayıları ile açıklanabilir. Nitekim uygulamaya katılan 3. sınıf öğrenci sayısının 4. sınıf öğrencilerinden daha fazla olduğu dolayısıyla 3. sınıf öğrencilerinin daha fazla kelime ve frekans değeri ürettikleri söylenebilir. 
Eğitsel Oyunların Öğrencilerin Sorumluluk Değeri ile İlgili Bilişsel Yaplarına Etkisi Var mıdır? Sorusuna Yönelik Bulgular

Araştırmaya katılan öğrencilerin sınıf düzeylerine göre uygulama öncesi ve sonrası sorumluluk değeri ile ilişkili bilişsel yapılarını gösteren kelimeler ve frekans değerleri tablo 5'de verilmiştir.

Tablo 5: Öğrencilerin Sorumluluk Değeri İle İlişsilendirdikleri Kelimelere Yönelik Oluşturulan Frekans Tablosu

\begin{tabular}{|c|c|c|c|c|c|c|}
\hline & 2. $\operatorname{Sinif}(\mathrm{N}=17)$ & $\mathrm{f}$ & 3. $\operatorname{Sinif}(\mathrm{N}=22)$ & $\mathrm{f}$ & 4. $\operatorname{Sinif}(\mathrm{N}=15)$ & $\mathrm{f}$ \\
\hline \multirow{14}{*}{ Ön test } & Ödev yapmak & 9 & Görev & 11 & Görev & 12 \\
\hline & Odayı toplamak & 8 & Ödev yapmak & 9 & Ödev yapmak & 6 \\
\hline & Yardım etmek & 2 & Ders çalışmak & 7 & Odayı toplamak & 5 \\
\hline & İyi öğrenci olmak & 1 & Okula gitmek & 5 & Kardeşe bakmak & 3 \\
\hline & Kitap okumak & 1 & Çantayı hazırlamak & 3 & Temiz olmak & 3 \\
\hline & Ders çalışmak & 1 & Kitap okumak & 2 & Yatak toplamak & 1 \\
\hline & Hayvanlara iyi davranmak & 1 & Erken kalkmak & 1 & Öğretmeni dinlemek & 1 \\
\hline & Engellilere iyi davranmak & 1 & Odayı toplamak & 1 & Ekmek almak & 1 \\
\hline & İşleri zamanında yapmak & 1 & Yatak düzeltmek & 1 & & \\
\hline & Çantayı hazırlamak & 1 & Evdeki sorumluluklar & 1 & & \\
\hline & Görev & 1 & Yardım etmek & 1 & & \\
\hline & Çöpleri toplamak & 1 & Kardeşe bakmak & 1 & & \\
\hline & Yatak toplamak & 1 & & & & \\
\hline & Okula zamanında gitmek & 1 & & & & \\
\hline Toplam & Kelime sayısı $=14$ & 30 & Kelime sayısı $=12$ & 43 & Kelime sayısı $=8$ & 32 \\
\hline \multirow{15}{*}{ Son test } & Ödev yapmak & 7 & Ödev yapmak & 10 & Görev & 8 \\
\hline & Odayı toplamak & 12 & Ders çalışmak & 9 & Ödev yapmak & 5 \\
\hline & Yardım etmek & 3 & Okula gitmek & 1 & Kitap okumak & 2 \\
\hline & Ders çalışmak & 1 & Odayı toplamak & 10 & Ekmek almak & 1 \\
\hline & Çantayı hazırlamak & 1 & Ekmek almak & 8 & Temizlik yapmak & 2 \\
\hline & Görev & 5 & Yatak toplamak & 4 & Okula gitmek & 2 \\
\hline & Yatak toplamak & 4 & Kiyafetleri toplamak & 2 & Odayı toplamak & 3 \\
\hline & Dolap toplamak & 1 & Kitap okumak & 4 & Çevreyi temiz tutmak & 4 \\
\hline & Düzenli olmak & 1 & Askerlik yapmak & 1 & Yardım etmek & 1 \\
\hline & Sahip çıkmak & 2 & Çöpü çöpe atmak & 2 & & \\
\hline & Masayı toplamak & 1 & Oyuncakları toplamak & 2 & & \\
\hline & Kitap okumak & 1 & Kişisel bakım & 2 & & \\
\hline & & & Yardım etmek & 3 & & \\
\hline & & & Çantayı hazırlamak & 5 & & \\
\hline & & & Görev & 2 & & \\
\hline Toplam & Kelime say $1 s 1=12$ & 39 & Kelime sayıs1 $=15$ & 65 & Kelime say $1 \mathrm{~s} 1=9$ & 28 \\
\hline
\end{tabular}

Tablo 5'e göre 2. sınıf düzeyindeki öğrenciler eğitsel oyun öncesi sorumluluk değeri ile ilgili olarak 14 kelime ilişkilendirirken uygulama sonrası ilişkilendirdikleri kelime sayısı 12'ye inmiş ve frekans değeri 30'dan 39'a yükselmiştir. 3. sınıf düzeyindeki öğrenciler eğitsel oyun öncesi sorumluluk değeri ile ilgili olarak 12 kelime ilişkilendirirken uygulama sonrası ilişkilendirdikleri kelime 
sayısı 15'e çıkmış ve frekans değeri 43'den 65'e yükselmiştir. 4. sınıf düzeyindeki öğrenciler eğitsel oyun öncesi sorumluluk değeri ile ilgili olarak 8 kelime ilişkilendirirken uygulama sonrası ilişkilendirdikleri kelime sayısı 9'a çıkmış ancak frekans değeri 32'den 28'e inmiştir. Ayrıca uygulama sonrası 2 ve 3. sınıf öğrencilerinin ilişkilendirdikleri kelime sayıları ile frekans değerlerinin 4. sınıf öğrencilerinden daha fazla olması dikkat çekici bir sonuçtur. Ancak uygulamaya katılan öğrenci sayıları incelendiğinde 3. sınıf öğrencilerinin 4. sınıf öğrencilerinden daha fazla olduğu da dikkate alınmalıdır.

\section{Eğitsel Oyunların Öğrencilerin Sabır Değeri ile İlgili Bilişsel Yapla- rına Etkisi Var mıdır? Sorusuna Yönelik Bulgular}

Araştırmaya katılan öğrencilerin sınıf düzeylerine göre uygulama öncesi ve sonrası sabır değeri ile ilişkili bilişsel yapılarını gösteren kelimeler ve frekans değerleri tablo 6'da verilmiştir.

\begin{tabular}{|c|c|c|c|c|c|c|}
\hline & 2. $\operatorname{Sinif}(N=17)$ & $\mathrm{f}$ & 3. $\operatorname{Sinif}(N=22)$ & $\mathrm{f}$ & 4. $\operatorname{Sin} 1 f(N=23)$ & $\mathrm{f}$ \\
\hline \multirow{5}{*}{ Ön test } & Beklemek & 5 & Beklemek & 20 & Beklemek & 4 \\
\hline & Dayanmak & 1 & Anlayışlı olmak & 8 & Sakin olmak & 1 \\
\hline & & & Bıkmamak & 4 & Vaz geçmemek & 1 \\
\hline & & & Siniri kontrol etmek & 2 & Dayanmak & 1 \\
\hline & & & Sakin olmak & 1 & Sinirlenmemek & 1 \\
\hline Toplam & Kelime sayıs $1=2$ & 6 & Kelime say $1 \mathrm{~s} 1=5$ & 35 & Kelime sayıs $=5$ & 8 \\
\hline \multirow{7}{*}{ Son test } & Beklemek & 9 & Beklemek & 22 & Beklemek & 20 \\
\hline & Telaşlanmamak & 3 & Sakin olmak & 11 & Huzur & 5 \\
\hline & Sikınt1 & 2 & Kızmamak & 6 & Doğru zamanlama & 1 \\
\hline & Yerinde durmak & 1 & & & Sessiz olmak & 1 \\
\hline & & & & & Dayanmak & 1 \\
\hline & & & & & Çaba sarf etmek & 1 \\
\hline & & & & & Sakinlik & 1 \\
\hline Toplam & Kelime say1sı $=4$ & 15 & Kelime sayıs $=3$ & 39 & Kelime sayıs $=7$ & 30 \\
\hline
\end{tabular}

Tablo 6'ya göre 2. sınıf düzeyindeki öğrenciler eğitsel oyun öncesi sabır değeri ile ilgili olarak 2 kelime ilişkilendirirken uygulama sonrası ilişkilendirdikleri kelime sayısı 4'e ve frekans değeri 30'dan 39'a yükselmiştir. 3. sınıf düzeyindeki öğrenciler eğitsel oyun öncesi sabır değeri ile ilgili olarak 5 kelime ilişkilendirirken uygulama sonrası ilişkilendirdikleri kelime sayısı 3'e inmiş ancak frekans değeri 35'den 39'a yükselmiştir. 4. sınıf düzeyindeki öğrenciler eğitsel oyun öncesi sabır değeri ile ilgili olarak 5 kelime ilişkilendirirken uygulama sonrası ilişkilendirdikleri kelime sayısı 7'ye ve frekans değeri 8'den 30'a yükselmiştir. Ayrıca öğrenci sayıları bir birine yakın olmasına rağmen uygulama 
sonras1 3. sınıf öğrencilerinin frekans değerinin 4. sınıf öğrencilerinden daha fazla olması da dikkat çekici bir sonuçtur. Bu sonuç öğrencilerin hazırbulunuşluk düzeyleri arasındaki farklılıktan kaynaklandığ şeklinde yorumlanabilir.

\section{Eğitsel Oyunların Öğrencilerin Eşitlik Değeri ile İlgili Bilişsel Yap- larına Etkisi Var mıdır? Sorusuna Yönelik Bulgular}

Araştırmaya katılan öğrencilerin sınıf düzeylerine göre uygulama öncesi ve sonrası eşitlik değeri ile ilişkili bilişsel yapılarını gösteren kelimeler ve frekans değerleri tablo 7'de verilmiştir.

Tablo 7: Öğrencilerin Eşitlik Değeri İle İlişkilendirdikleri Kelimelere Yönelik Oluşturulan Frekans Tablosu

\begin{tabular}{|c|c|c|c|c|c|c|}
\hline & 2. $\operatorname{Sin} 1 f(N=15)$ & $f$ & 3. $\operatorname{Sin} 1 f(N=22)$ & $\mathrm{f}$ & 4. $\operatorname{Sin} 1 f(N=16)$ & $\mathrm{f}$ \\
\hline \multirow{9}{*}{ Ön test } & Terazi & 6 & Terazi & 4 & Adalet & 14 \\
\hline & Bölüşme & 6 & Adalet & 6 & Herkese aynı davranmak & 5 \\
\hline & Aynıs1 & 3 & Demokrasi & 5 & Kanun & 4 \\
\hline & Eşittir işareti & 1 & Aynı olması & 3 & Tarafsızlık & 2 \\
\hline & & & Tahterevalli & 3 & Aynı şartlar & 1 \\
\hline & & & Eşleşmek & 2 & Aynı olmak & 1 \\
\hline & & & Paylaşma & 1 & Terazi & 1 \\
\hline & & & Hak & 1 & & \\
\hline & & & Eşittir işareti & 3 & & \\
\hline Toplam & Kelime say1s $1=4$ & 16 & Kelime sayıs $1=9$ & 28 & Kelime sayıs1 $=7$ & 28 \\
\hline \multirow{8}{*}{ Son test } & Terazi & 6 & Hak & 19 & Adalet & 10 \\
\hline & Bölüşme & 2 & Aynı olması & 2 & Paylaşmak & 2 \\
\hline & Paylaşma & 5 & Terazi & 3 & Terazi & 10 \\
\hline & Aynis1 & 4 & Tahterevalli & 1 & Denge & 6 \\
\hline & & & Simetri & 1 & Kanun & 2 \\
\hline & & & Paylaşma & 3 & Aynı olmak & 1 \\
\hline & & & & & Tarafsızlık & 1 \\
\hline & & & & & Güven & 1 \\
\hline Toplam & Kelime say1s1 $=4$ & 17 & Kelime say1s1 $=6$ & 29 & Kelime sayısı $=8$ & 33 \\
\hline
\end{tabular}

Tablo 7'ye göre 2. sınıf düzeyindeki öğrenciler eğitsel oyun öncesi ve sonras1 eşitlik değeri ile ilgili olarak 4 kelime ilişkilendirirken frekans değeri 16'dan 17'ye yükselmiştir. 3. sınıf düzeyindeki öğrenciler eğitsel oyun öncesi eşitlik değeri ile ilgili olarak 9 kelime ilişkilendirirken uygulama sonrası ilişkilendirdikleri kelime sayısı 6'ya inmiş ve frekans değeri 28'den 29'a yükselmiştir. 4. sınıf düzeyindeki öğrenciler eğitsel oyun öncesi eşitlik değeri ile ilgili olarak 7 kelime ilişkilendirirken uygulama sonrası ilişkilendirdikleri kelime sayısı 8'e ve frekans değeri 28 'den 33'e yükselmiştir. 
Eğitsel Oyunların Öğrencilerin Dayanışma Değeri ile İlgili Bilişsel Yaplarına Etkisi Var mıdır? Sorusuna Yönelik Bulgular

Araştırmaya katılan öğrencilerin sınıf düzeylerine göre uygulama öncesi ve sonrası dayanışma değeri ile ilişkili bilişsel yapılarını gösteren kelimeler ve frekans değerleri tablo 8'de verilmiştir.

Tablo 8: Öğrencilerin Dayanışma Değeri Ile Ilişkilendirdikleri Kelimelere Yönelik Oluşturulan Frekans Tablosu

\begin{tabular}{|c|c|c|c|c|c|c|}
\hline & 2. $\operatorname{Sin} I f(N=13)$ & f & 3. Sinıf $(N=18)$ & $\mathbf{f}$ & 4. Sinıf $(N=15)$ & f \\
\hline \multirow{5}{*}{ Ön test } & Yardımlaşma & 2 & Yardımlaşma & 19 & Birlik beraberlik & 10 \\
\hline & Yan yana olmak & 1 & Paylaşmak & 10 & Kurtuluş savaşı & 8 \\
\hline & Güven & 1 & Birlik beraberlik & 7 & Toplum & 6 \\
\hline & Duyarlılık & 1 & Destek & 1 & Çanakkale savaşı & 1 \\
\hline & & & & & Milli mücadele & 1 \\
\hline Toplam & Kelime sayısı=4 & 5 & Kelime sayısı=4 & 37 & Kelime sayısı $=5$ & 26 \\
\hline \multirow{6}{*}{ Son test } & Yardımlaşma & 9 & Yardımlaşma & 17 & Birlik beraberlik & 5 \\
\hline & Beraberlik & 1 & Paylaşmak & 14 & Kurtuluş savaşı & 2 \\
\hline & Paylaşmak & 1 & El ele vermek & 4 & Toplum & 2 \\
\hline & Vermek & 1 & İyilik & 2 & Yardımlaşma & 10 \\
\hline & & & Bencil olmamak & 3 & Paylaşmak & 2 \\
\hline & & & & & Güven & 1 \\
\hline Toplam & Kelime sayısı $=4$ & 12 & Kelime sayısı $=\mathbf{5}$ & 40 & Kelime sayısı $=6$ & 22 \\
\hline
\end{tabular}

Tablo 8'e göre 2. sınıf düzeyindeki öğrenciler eğitsel oyun öncesi ve sonras1 dayanışma değeri ile ilgili olarak 4 kelime ilişkilendirirken frekans değeri 5 'den 12’ye yükselmiştir. 3. sınıf düzeyindeki öğrenciler eğitsel oyun öncesi dayanışma değeri ile ilgili olarak 4 kelime ilişkilendirirken uygulama sonrası ilişkilendirdikleri kelime sayısı 5'e ve frekans değeri 37'den 40'a yükselmiştir. 4. sınıf düzeyindeki öğrenciler eğitsel oyun öncesi dayanışma değeri ile ilgili olarak 5 kelime ilişkilendirirken uygulama sonrası ilişkilendirdikleri kelime sayısı 6'ya yükselmiş ancak frekans değeri 26'dan 22'ye inmiştir. Ayrıca öğrenci sayılarının bir birine yakın olmasına rağmen uygulama sonrası 3. sınıf öğrencilerinin frekans değerinin 4. sınıf öğrencilerinden daha fazla olması da dikkat çekici bir sonuçtur. Bu sonuç öğrencilerin hazırbulunuşluk düzeyleri arasındaki farklılıktan kaynaklandı̆̆

\section{Eğitsel Oyunların Öğrencilerin Adalet Değeri ile İlgili Bilişsel Yap- larına Etkisi Var mıdır? Sorusuna Yönelik Bulgular}

Araştırmaya katılan öğrencilerin sınıf düzeylerine göre uygulama öncesi ve sonrası adalet değeri ile ilişkili bilişsel yapılarını gösteren kelimeler ve frekans değerleri tablo 9' da verilmiştir. 


\begin{tabular}{|c|c|c|c|c|c|c|}
\hline & 2. $\operatorname{Sin} ı f(N=14)$ & $\mathrm{f}$ & 3. $\operatorname{Sin} 1 f(N=20)$ & $\mathrm{f}$ & 4. $\operatorname{Sin} 1 f(N=16)$ & $\mathrm{f}$ \\
\hline \multirow{8}{*}{ Ön test } & Hak & 2 & Hâkim & 6 & Eşitlik & 11 \\
\hline & Adil & 1 & Save1 & 5 & Kanunlar & 5 \\
\hline & Ayrımcilık yapmamak & 1 & Mahkeme & 3 & Mahkeme & 2 \\
\hline & Eşit davranmak & 1 & Avukat & 4 & Demokrasi & 2 \\
\hline & & & Polis & 3 & Hak & 2 \\
\hline & & & Hak & 2 & Hâkim & 1 \\
\hline & & & Eşitlik & 5 & Herkese aynı davranmak & 1 \\
\hline & & & Adil davranmak & 1 & Adil olmak & 1 \\
\hline Toplam & Kelime sayısı $=4$ & 5 & Kelime sayısı $=8$ & 29 & Kelime sayısı $=8$ & 25 \\
\hline \multirow{9}{*}{$\begin{array}{l}\text { Son } \\
\text { test }\end{array}$} & Eşit davranmak & 7 & Hâkim & 5 & Eşitlik & 10 \\
\hline & Hak & 2 & Savc1 & 4 & Güven & 4 \\
\hline & Adil & 1 & Mahkeme & 3 & Paylaşma & 4 \\
\hline & Ayırt etmemek & 1 & Avukat & 3 & Hâkim & 2 \\
\hline & & & Polis & 3 & Kanun & 2 \\
\hline & & & Hak & 3 & Hak & 3 \\
\hline & & & Eşitlik & 6 & Mahkeme & 1 \\
\hline & & & Adil davranmak & 2 & & \\
\hline & & & Ayırt etmemek & 2 & & \\
\hline Toplam & Kelime sayısı $=4$ & 11 & Kelime say $1 \mathrm{~s} 1=9$ & 31 & Kelime say $1 \mathrm{~s} 1=7$ & 26 \\
\hline
\end{tabular}

Tablo 9'a göre 2. sinıf düzeyindeki öğrenciler eğitsel oyun öncesi ve sonras1 dayanışma değeri ile ilgili olarak 4 kelime ilişkilendirirken frekans değeri 5'den 11'e yükselmiştir. 3. sınıf düzeyindeki öğrenciler eğitsel oyun öncesi dayanışma değeri ile ilgili olarak 8 kelime ilişkilendirirken uygulama sonrası ilişkilendirdikleri kelime sayıs1 9'a ve frekans değeri 29'dan 31'e yükselmiştir. 4. sınıf düzeyindeki öğrenciler eğitsel oyun öncesi dayanışma değeri ile ilgili olarak 8 kelime ilişkilendirirken uygulama sonrası ilişkilendirdikleri kelime sayısı 7'ye inmiş ancak frekans değeri 25'den 26'ya yükselmiştir. Ayrıca uygulama sonras1 3. sınıf öğrencilerinin kelime sayısının ve frekans değerinin 4. sınıf öğrencilerinden daha fazla olması dikkat çekici bir sonuçtur. Ancak uygulamaya katılan öğrenci sayıları incelendiğinde 3. sınıf öğrencilerinin 4. sınıf öğrencilerinden daha fazla olduğu da görülmektedir.

\section{Eğitsel Oyunların Öğrenciler Üzerindeki Etkisine Yönelik Öğret- men Görüşleri Nelerdir? Sorusuna Yönelik Bulgular}

Değer kazandırmaya yönelik tasarlanan eğitsel oyunların öğrenciler üzerindeki etkisine yönelik öğretmen görüşleri Tablo 10'da verilmiştir. Öğretmen görüşlerinin yedi başlık altında şekillendiği görülmektedir. 
Tablo 10: Eğitsel Oyunların Öğrenciler Üzerindeki Etkisi Hakkındaki Öğretmen Görüşleri

\begin{tabular}{lc}
\hline Temalar & f \\
\hline Eğitsel oyunlar değer kazandırmada etkiliydi & 3 \\
\hline Öğrenciler eğitsel oyunları eğlenerek oynadılar & 3 \\
\hline Öğrenciler eğitsel oyunlara katılmada istekliydiler & 3 \\
\hline Eğitsel oyunların oynanmasında herhangi bir zorluk yaşamadım & 2 \\
\hline Oyunlar genel olarak sınıf seviyesine uygundu & 3 \\
\hline Bazı oyunlar sınıf seviyesinin altında, bazıları da üstündeydi & 1 \\
\hline Bazı oyunlarda küçük düzenlemeler yapıllabilir & 2 \\
\hline
\end{tabular}

Kalıcı öğrenmelerin gerçekleşebilmesi için öğrenenin derse katılımı, yaparak yaşayarak öğrenmesi ve öğrenme yaşantılarının öğrenenin gelişim düzeyine uygunluğu öğretimin önemli üç ilkesidir. Eğitsel oyunların tasarımında öğretimin bu üç önemli (katılım, aktivite, çocuğa görelik) ilkesi merkeze alınmıştır. Öğrencilerin gelişim düzeylerine uygun eğitsel oyunlar ile öğrenme yaşantıları gerçekleştirebilmeleri ve her bir öğrencinin bu öğrenme yaşantılarına eğlenerek katılımlarının sağlanması hedeflenmiştir. Bu süreçle ilgili bazı öğretmen görüşleri şu şekildedir:

“...sinıfimda uyguladı̆̆ım eğitsel oyunlarla öğrencilerimin eğlenirken kazandlrılması amaçlanan değeri de içselleştirdiğini gözlemledim. Değerler soyut bir kavram iken oyunlarla somut hale gelmesine, özümsenmesine, farkındalık oluşturmasına, kalıcı davranışa dönüşmesine vesile olmuştur.” (3. Sınıf Öğretmeni)

"Yardımlaşma ve dayanışma istasyonu ile ilgili etkinliğin çocuklar üzerinde etkili olduğunu gördüm. Birbirlerine yardımcı olmak için çabaladılar...” (2. Sınıf Öğretmeni)

"Oyunlara istekli olarak katıldılar. Zevk alarak etkinlikleri gerçekleştirdiler." (4. Sınıf Öğretmeni)

"Adalet etkinliği adalet ile eşitlik arasındaki farkı net bir şekilde anlamalarını sağladı ... yardımlaşma ve dayanışma etkinliği zevkle yaptıkları bir etkinlik oldu. Daha çok 3 ve 4. sinıf seviyesine uygun bir etkinlik.” (4. Sınıf Öğretmeni)

“...örneğin dürüstlük oyunundan sonra bir ögrencim yanıma gelerek, ögretmenim dolabınızdan not kâğıtlarından iki tane aldım bunu size söylemek istedim, diyerek önceden kendilerine bu not kâğttlarını ihtiyacınız halinde kullanabilirsiniz dememe rağmen içinin rahat etmeyeceği düşüncesiyle bu durumu bana söylemek gereği hissetmiştir. Bu durumun oyunun etkisinden kaynaklandiğını düşünüyorum." (3. Sınıf Öğretmeni) 
"Hangi masa sorumlu çalışmamızda en büyük sorunumuz tahtaya yazılan sorumlulukla ilgili cümleleri diğer grupların görmesi... Gruplara kâğıt verilerek kâğıda yazmaları bence daha doğru olur.” (2. Sınıf Öğretmeni)

"En etkili etkinliğimiz Adalet Eşitlik midir? etkinliğiydi. Çocuklar çok eğlendi. Diğer etkinlikleri uygulamada da bir sıkıntı yaşamadık.” (2. Sınıf Öğretmeni)

“Toplumumuzun genelinde hâkim olan sabırsızlık çocuklarımızda da var. Parmak kaldırmadan konuşma, arkadaşına söz verilmişken araya girme, acelecilik vb. olumsuz durumlarla karşılaşmaktayım. Sabır oyununda bu olumsuzlukların oldukça azaldığını gözlemledim. Keyifle oynadıkları bu oyundan sonra parmak kaldırarak söz almaya, arkadaşı söz almışken araya girmemeye daha fazla özen gösterdiler.” (3. Sınıf Öğretmeni)

\section{Eğitsel Oyunların İlköğretim Programlarında Yer Alan Derslerin Kazanımları ile İlişkisine Yönelik Öğretmen Görüşleri Nelerdir? Sorusuna Yönelik Bulgular}

Araştırmacı tarafından tasarlanan eğitsel oyunların ilköğretim programlarında yer alan derslerin kazanımları ile ilişkili olup olmadığına yönelik öğretmen görüşleri tablo 11 'de verilmiştir. Öğretmen görüşleri tek başlık altında toplandığı görülmektedir.

Tablo 11: Eğitsel Oyunların Kazanımlar İle İlişkili Olup Olmadığına Yönelik Öğretmen Görüşleri

\begin{tabular}{ll}
\hline Temalar & f \\
\hline Eğitsel oyunlar öğretim programlarındaki kazanımlarla ilişkilidir & 3 \\
\hline
\end{tabular}

Eğitsel oyunlar öğretim programlarında yer alan ilgili derslerin kazanımları ile ilişkilendirilerek söz konusu kazanımları gerçekleştirmeye yönelik destekleyici bir etkinlik/faaliyet olarak tasarlanmıştır. Diğer bir deyişle ilköğretim programlarında yer alan değerler kapsamında öğrencilere sunulan bilişsel ağırlıklı ders etkinliklerinin duyuşsal alan ile ilişkilendirilerek öğretimin bütünlük ilkesi gerçekleştirilmeye çalışılmıştır. Bu noktada bazı öğretmen görüşleri aşağıda sunulmuştur.

“Oyunlar ilköğretim programında yer alan kazanımlar ile ilişskilidir. ”(2. Sınıf Öğretmeni)

“Oyunlar konu ve kazanımlar ile ilişkilidir...”(3. Sınıf Öğretmeni)

“Eğitsel oyunlar derslerin kazanımları ile uyumludur... ”(4. Sınıf Öğretmeni) 


\section{Değerler Eğitiminde Eğitsel Oyunlara Yer Verilip Verilmemesine Yönelik Öğretmen Görüşleri Nelerdir? Sorusuna Yönelik Bulgular}

Eğitsel oyunlara öğretim programlarında yer verilip verilmemesine yönelik öğretmen görüşleri tablo 12'de verilmiştir. Öğretmen görüşlerinin iki başlık altında şekillendiği görülmektedir.

Tablo 12: Eğitsel Oyunlara Öğretim Programlarında Yer Verilip Verilmemesine Yönelik Öğretmen Görüşleri

\begin{tabular}{ll}
\hline Temalar & f \\
\hline Eğitsel oyunlar ders kitaplarında doğrudan yer almalıdır & 2 \\
\hline Eğitsel oyunlar destekleyici faaliyet olmalıdır & 1 \\
\hline
\end{tabular}

Eğitsel oyunlara öğretim programlarında yer verilip verilmemesine yönelik öğretmen görüşleri aşağıda sunulmuştur.

“İlköğretim programımızda değerler ĕgitimi tema olarak mevcut. Değerlerin kazandırılmasında metinlerin işlenmesinin yanı sıra bu tür oyunlarla desteklenmesi daha kalıcı bir sonuç doğuracaktır. Bizzat kendim bunu denemiş ve olumlu sonuçlarını görmüş bir öğretmen olarak bundan sonrada kullanacă̆ım ... Eğgitsel oyunlara kesinlikle yer verilmelidir. Bu oyunların MEB tarafindan yönergesinin ve kurallarının belirlenmesinin daha uygun olacağını düşünüyorum." (3. Sınıf Öğretmeni)

"Kazanımlara uygun etkinlikler oluşturulmuş. Derslerde doğrudan yer alması bana göre daha etkili olur. Destekleyici olursa herkes uygulamayabilir." (4. S1nıf Öğretmeni)

“Değerler ĕgitiminde eğitsel oyunlara yer verilmeli, ders kitaplarında yer almalıdır... Bu sayede ögrenciler hem sosyal yönden gelişir hem de problem çözme becerileri kazanırlar.” (2. Sınıf Öğretmeni)

\section{Tartışma, Sonuç ve Öneriler}

Eğitsel oyunlar öncesi ve sonrası öğrencilere uygulanan kelime ilişkilendirme testinin analizinde şu sonuçlara ulaşılmıştır. Uygulama sonrasında 2. sınıf düzeyinde dürüstlük, dostluk, sabır, eşitlik, dayanışma, adalet değerleri ile ilişkilendirilen toplam kelime sayılarının ve frekans değerlerinin arttığı görülmüştür. 3. sınıf düzeyinde dürüstlük, dostluk, sorumluluk, dayanışma, adalet değerleri ile ilişkilendirilen toplam kelime sayılarının ve frekans değerlerinin arttığ görülmüştür. 4. sınıf düzeyinde dürüstlük, dostluk, sabır, eşitlik değerleri ile ilişkilendirilen toplam kelime sayılarının ve frekans değerlerinin arttığı gö- 
rülmüştür. Yine uygulama sonrasında 2. sınıf düzeyinde sorumluluk, 3. sınıf düzeyinde sabır ve eşitlik, 4. sınıf düzeyinde adalet değerlerinde ilişkilendirilen toplam kelime sayılarında küçük bir düşüş görülse de frekans değerlerinde artış gözlemlenmiştir. Bu durum değer kazanımı açısından olumlu bir sonuç olarak yorumlanabilir. Çünkü adı geçen değerlerle ilgili olarak sınıf düzeyinde ilişkilendirilen kelimelerin uygulama öncesine göre daha fazla tekrarlanması söz konusudur. Öğretmen görüşlerinin analizinde de bu bulguları destekleyen sonuçlara ulaşılmıştır. Şöyle ki; öğretmenler eğitsel oyunların değer kazandırmada etkili olduğunu ve destekleyici bir faaliyet olarak ders kitaplarında doğrudan yer alması gerektiğini belirterek öğrencilerin eğitsel oyunlar ile uygulama sonrası değer kazanımında olumlu yönde etkilendiklerini işaret etmektedirler. Nitekim Genç, Tutkun, ve Çoruk'un (2015) araştırmasında öğretmenler, değerler eğitiminin öğrenci merkezli anlayışla ve çeşitli etkinliklerle gerçekleştirilmesi gerektiğini belirtmişlerdir. Literatürde araştırmanın bulgularını destekler nitelikteki çalışmalara da rastlanmaktadır. Butler (2013) araştırmasında oyuna dayalı etkinliklerin sosyal ve etik anlayışı öğretmek için önemli avantajlar sağladığı sonucuna ulaşılmıştır. Araştırmada oyunların ahlaki gelişimde önemli bir araç olarak kullanılabileceğinden bahsedilmiştir. Bolat'ın (2018) araştırmasında ilkokul öğrencilerinin eğitsel oyunu öğretici, eğlendirici, gerçek hayata yönelik, şaşırtıcı, hakları savunmaya yönelik ve yaratıcı buldukları belirlenmiştir. Eliasa'nın (2014) araştırmasında öğrencilerde işbirliğini artırma, daha fazla sorumluluk oluşturma gibi becerilerin oyunlarla kazandırıldığı sonucuna ulaşılmıştır. Erdal'ın (2019) araştırmasında ise geleneksel çocuk oyunları incelenmiş ve bu oyunların çocuklara çeşitli değerleri kazandırabileceği sonucuna ulaşılmıştır. Ayrıca bazı araştırmalarda eğitsel oyunlarla desteklenen öğretimin akademik başarıyı olumlu yönde etkilediği, öğrenme ve öğretme sürecine olumlu etkileri olduğu görülmüşsür. (Bayat, Kılıçaslan \& Şentürk; Biter \& Çalışkan, 2019; 2014; Gürer \& Arslan, 2017). Yine Altunay'ın (2004) yapmış olduğu deneysel araştırmada oyunla desteklenmiş matematik dersinin öğretiminde öğrenci erişisi ve öğrenilenlerin kalıcılığı üzerinde deney grubu lehine anlamlı bir farklılık görülmüştür.

Diğer taraftan kelime ilişkilendirme testinin analizinde düşündürücü bulgulara da ulaşılmıştır. Uygulama sonrasında 4. Sınıf düzeyinde dürüstlük, sorumluluk ve dayanışma değerleri ile ilgili olarak ilişkilendirilen toplam kelime sayılarında uygulama öncesine göre bir artış görülse de frekans değerlerinde küçük düşüşler olduğu gözlemlenmiştir. Bu durum öğrencilerin söz konusu değer ile ilgili eğitsel oyuna katılımında güçlük çekmiş olabileceği, uygulama esnasın- 
da motivasyonel sorunlar yaşamış olabileceği veya oyun ile söz konusu değeri bilişsel olarak ilişkilendirememiş olabileceği şeklinde açıklanabilir. Öğretmen görüşlerinin analizinde de bu yorumu destekler nitelikte temalar bulunmaktadır. Şöyle ki; araştırmaya katılan öğretmenler bazı oyunlarda küçük düzenlemelerin yapılabileceğini ve bazı oyunların sınıf seviyesinin altında, bazılarının da üstünde olduğunu belirtmişlerdi. Nitekim Biter ve Çalışkan’nın (2019) araştırmasında da benzer sonuçlar görülmüştür. Şöyle ki; oyunlarda seçilen öğrencilerin yorum gücünün zayıf olması, süre planlamasında sorunların yaşanması ve sınırlı sayıda öğrencinin katılması gibi sebeplerden ötürü öğrencilerin derste sıkıldığ1 gözlemlenmiştir. Gündüz, Aktepe, Uzunoğlu ve Gündüz (2017) bu durumu şu şekilde açıklamaktadır. Doğru-yanlış, güzel-çirkin, iyi-kötü, hak11-haksız gibi kavramları çocuk oyun sırasında görür, dener ve kendi fikriyle çatışmıyorsa onu benimseyerek kendisinin bir parçası yapar. Kendine uymuyorsa yinelemez ve öğrenmez. Dolayısıyla Yeşilyurt (2019) oynanan eğitsel oyunun kurallarının söylenmesi, uygulanması, aralarındaki bağlantıların saptanması, analiz edilmesi, oyunun kurallarına göre yapılıp yapılmadığın değerlendirilmesi gerektiğini ifade etmektedir. Ayrıca çocuğun oynanan oyuna kendini adaması, kurallara uymada süreklilik göstermesi, kurallara uymayı kendine iş edinmesi, kuralları kendi içerisinde çelişmemek şartıyla güncellemesi gibi davranışları da sergilemesi gerektiğini belirtmektedir.

Bir diğer çarpıcı bulgu ise eşitlik değeri hariç diğer değerlerin hepsinde 3. sınıf toplam kelime sayılarının ve/veya frekans değerlerinin 4. sınıfınkilerden hem uygulama öncesi hem de uygulama sonrası yüksek olmasıdır. Dostluk, sorumluluk ve adalet değerleri için bu farklılığın kaynağı olarak sınıflardaki öğrenci sayıları gösterilebilir. Yani söz konusu değerlerle ilgili oyunlara katılan öğrenci sayıları incelendiğinde 3. sınıf öğrenci sayısının daha fazla olduğu görülmektedir. Ancak dürüstlük, sabır ve dayanışma değerleri için bu farklılık oyunlara katılan öğrenci sayıları ile açıklanamamaktadır. Çünkü oyuna katılan öğrenci sayıları bir birine çok yakındır. Bu durumda farklılığın kaynağı olarak öğrencilerin hazırbulunuşluk düzeyleri gösterilebilir. Dolayısıyla söz konusu değerlerle ilişkili olarak 3. sınıf öğrencilerinin daha fazla yaşantıya sahip olduğu söylenebilir. Nitekim eğitim sistemimiz içerisinde sınıflar arasında hazıbulunuşluk düzeylerinde farkl1lıkların olabileceği bilinmektedir. Özgan ve Tekin'in (2011) araştırmasında öğretmenler, öğrencilerin hazırbulunuşluk düzeylerinde yaşanan yetersizliğe neden olan başlica etken olarak öğrenci ve velileri göstermişlerdir. Öğretmenler öğrencilerin bir alt kademeden yetersiz gelmesi sorununu sıkça vurgulamış ve öğrenme-öğretme sürecinde bazı eksikliklerin yaşandığını be- 
lirtilmişlerdir. Yine Canbulat'ın (2017) ilkokul öğrencilerinin okula uyum ve okula hazır bulunuşluk düzeylerini incelediği araştırmasında okul öncesi eğitimi alan öğrencilerin hazır bulunuşluk düzeylerinin yüksek olduğu sonucuna ulaşılmıştır.

Diğer taraftan Uzun ve Köse'nin (2017) değerler eğitimi ile ilgili öğretmen görüşlerini incelendiği araştırmasında ise değerlerin Türkçe ve drama etkinliklerinde ele alındığı, bu kapsamında çoğunlukla resmi kurum ve kuruluşlara yönelik geziler düzenlendiği, değerlerin kazandırılmasında en fazla öğrenci ve aile kaynaklı nedenlerden dolayı zorluklar yaşandığı sonuçlarına ulaşılmıştır. Dolayısıyla araştırmamızda değerlerin kazanımı sürecinin eğitsel oyunlar ile zenginleştirilmesi, öğrencilerin bu etkinliklere severek katılmaları ve öğretmenlerin değer öğretiminde herhangi bir zorluk yaşamamış olmaları değerler eğitiminde eğitsel oyunlara yer verilmesinin önemi hakkında bir fikir verebilir. Öğretmenlerin görüşleri ile ilgili temalar incelendiğinde öğretmenlerin, öğrencilerin eğitsel oyunları eğlenerek oynadılarını, eğitsel oyunlara katılmada istekli olduklarını, eğitsel oyunların oynanmasında herhangi bir zorluk yaşamadıklarını ve oyunların genel olarak sınıf seviyesine uygun olduğu yönündeki ifadeleri bu yorumu destekler niteliktedir. Nitekim Yeşilyurt ve Kurt'a (2012) göre s1nıfta düzenlenen yarışma, tartışma, oyun, drama, skeç vb. etkinliklerin nitelikli yapılması, değerlerin kazandırılmasında resmi program yollarının etkililiğini yükseltecektir. Literatürde araştırma bulgusunu destekler nitelikte çalışmalara da rastlanmaktadır. Karamustafaoğlu, Pazar ve Karamustafaoğlu'nun (2018) çalışmasında eğitsel oyun etkinliklerinin öğrenciyi hem eğlendirip hem de derse karşı ilgisinin artmasını sağladığı yönünde sonuçlara ulaşılmışlardır. Yine Biter ve Çalışkan'ın (2019) araştırmasında eğitsel oyunların bir eğitim aracı olarak kullanılması neticesinde öğrencilerin eğlenerek öğrendiği, derse olan ilgilerinin arttığı ve yaşantı geçirerek öğrenmelerini sağladığı sonucu ortaya çıkmıştır.

Sonuç olarak ilkokul öğretim programlarında yer alan dürüstlük, dostluk, sorumluluk, sabır, eşitlik, dayanışma, adalet değerlerini kazandırmaya yönelik tasarlanan eğitsel oyunların öğrencilerin bilişsel yapılarını genel olarak olumlu yönde etkilediği görülmüştür. Ayrıca öğretmen görüşlerine göre eğitsel oyunların öğretim programlarındaki kazanımlarla ilişkili olduğu, öğrencilere söz konusu değerleri somut yaşantı olarak tecrübe etme imkânı verdiği, öğrencilerin eğitsel oyunlara katılmada istekli oldukları ve eğlenerek oynadıkları, eğitsel oyunların oynanmasında herhangi bir zorluk yaşanmadığı sonuçlarına da ulaşılmıştır. Ancak öğretmenler dayanışma ve sorumluluk değerlerini 2. sınıf 
öğrencilerinin daha iyi anlamlandırabilmesi için bu değerlere ait oyunlarda küçük düzenlemelerin yapılması gerektiğini de belirtilmiştir. Buradan hareketle araştırma bulgularına göre şu önerilerde bulunulabilir:

Tasarlanan eğitsel oyunlardan dayanışma değeri ile ilgili oyunda istasyon tekniği kullanılarak yardımlaşma ve dayanışma değerleri kazandırılmaya çalışılmıştır. 2. sınıf öğrencilerinin bu iki değer arasındaki ince ayrımı anlayabilmeleri için ipucuna dayalı önermelerin oyun yönergesinde belirtilmesi önerilebilir.

Tasarlanan eğitsel oyunlardan sorumluluk değeri ile ilgili oyunda sınıf içerisinde grup çalışması yapılmıştır. Grupların birbirlerini etkilenmemelerini sağlayacak ortamların oluşturulması önerilebilir.

Değerlerin kazanımında derslerde uygulanan etkinliklere ek olarak bu tür eğitsel oyunlarla somut yaşantılar sağlayabilecek faaliyetler ilkokul öğretim programlarına eklenebilir.

Değerlerin öğretiminde soyut kavramların somutlaştırılabilmesinde bu tür eğitsel oyunlardan faydalanılabilir.

\section{Kaynakça}

Altunay, D. (2004). Oyunla desteklenmiş matematik öğretiminin öğrenci erişisine ve kalıcllı̆̆a etkisi.(Yayınlanmamış yüksek lisans tezi). Gazi Üniversitesi, Ankara.

Bahar, M., Johnstone, A.H. \& Sutcliffe, R. (1999). Investigation of students' cognitive structure in elementary genetics through word association tests. Journal of Biological Education, 33(3), 134-141.

Bahar, M. \& Özatlı, S. (2003). Kelime iletişim test yöntemi ile lise 1. sınıf öğrencilerinin canlıların temel bileşenleri konusundaki bilişsel yapılarının araştırılmas1. BAÜ Fen Bil. Enst. Dergisi, 5(2), 75-85.

Bayat, S., Kılıçaslan, H. \& Şentürk, Ş. (2014). Fen ve teknoloji dersinde eğitsel oyunların yedinci sınıf öğrencilerinin akademik başarısına etkisinin incelenmesi. Abant İzzet Baysal Üniversitesi Eğitim Fakültesi Dergisi, 14(2), 204-216.

Biter, M. \& Çalışkan, H. (2019). Sosyal bilgiler derslerinde eğitsel oyunlarla değerler eğitimi: Bir eylem araştırması. Journal of Interdisciplinary Education: Theory and Practice, 1(1), 1-28.

Bolat, H. (2018). Değerlerimle değerleniyorum eğitsel oyununun metaforik açıdan incelenmesi. Journal of Continuous Vocational Education and Training, 1(1), 29-39.

Butler, J. (2013). Situating ethics in games education. Canadian Journal of Education. 36(4), 93-114. 
Canbulat, T. (2017). Kesintili zorunlu eğitimden etkilenen ilkokul birinci sınıf öğrencilerinin okula uyum ve okula hazır bulunuşluk düzeylerinin değerlendirilmesi. Kastamonu Ĕ̆itim Dergisi, 25(4), 1573-1586.

Dündar, H. \& Hareket, E. (2016). Değerler eğitimi araştırmalarında yönelimler: Değerler eğitimi dergisi örneği. Akademik Baklş Dergisi, 55, 207-231.

Eliasa, E.I. (2014). Increasing values of teamwork and responsibility of the students through games: Integrating education character in lectures. Procedia-Social and Behavioral Sciences, 123, 196-203.

Erdal, K. (2019). Çocuk oyunlarında değerler eğitimi. Uluslararası insan ve sanat araştırmaları dergisi, 3(2), 53-59.

Genç, S.Z., Tutkun, T. \& Çoruk, A. (2015). Değer ve eğitimi sorunsalı: Sınıf öğretmenlerinin görüşlerine göre durum tespiti. Eğitimde Kuram ve Uygulama, 11(2), 374-397.

Gürer, B. \& Arslan, N. (2017). Din Kültürü ve Ahlak Bilgisi Dersinde eğitsel oyun yöntemi ile öğretimin öğrenci başarısına ve derse tutumuna etkisi. Değerler Eğitimi Dergisi, 15(34), 87-127.

Gündüz, M., Aktepe, V., Uzunoğlu, H. \& Gündüz; D.D. (2017). Okul öncesi dönemdeki çocuklara eğitsel oyunlar yoluyla kazandırılan değerler. $M S K U$ Eğitim Fakültesi Dergisi 4(1), 61-70.

Halstead, J.M. \& Taylor, M.J. (2000). Learning and teaching about values: a review of recent research. Cambridge Journal of Eucation, 30(2), 169-202.

Izgar, G. (2017). İnsan hakları, yurttaşlık ve demokrasi ders kitabının yapılandırmacı yaklaşım açısından analizi. İlköğretim Online, 16(2), 584-600.

Izgar, G. (2020). İlkokul değer öğretiminde eğitsel oyun kullanımı. İçinde M.Alkış Küçükaydın (Ed.), Illkokul eğitiminde eğitsel oyunlar ve güncel uygulamalar (ss:263-288). Ankara: Nobel Akademik Yayıncılık.

Karamustafaoğlu, O., Pazar, Ş.B. \& Karamustafaoğlu, S. (2018). Eğitsel oyunlarla Dolaşım Sistemi konusunun öğretimi: Kan yolu oyunu örneği. Eskişehir Osmangazi Üniversitesi Türk Dünyası Uygulama ve Araştırma Merkezi Eğitim Dergisi, 3(2), 1-18.

Kaymakcan, R. \& Meydan, H. (2011). Din Kültürü ve Ahlâk Bilgisi Programları ve Öğretmenlerine Göre Değerler Eğitimi. Değerler Eğitimi Dergisi, 9(21), 27-51.

Koçyiğit, S., Tuğluk, M.N. \& Kök, M. (2007). Çocuğun gelişim sürecinde eğitsel bir etkinlik olarak oyun. Journal of Kazim Karabekir Education Faculty 16, 324-342.

Kupchenko, I. \& Parsons, J. (1987). Ways of Teaching Values: An Outline of Six Values Approaches. ERIC: Document Resume Ed 288806 
Miles, M.B. \& Huberman, A.M. (1994). Qualitative data analysis: An expanded sourcebook (2nd Edition). Calif: SAGE Publications.

Milli Eğitim Bakanlığı. (2010). 2010/53 Sayılı İlk Ders Genelgesi.

Milli Eğitim Bakanlığı. (2018). Öğretim Programları İzleme ve Değerlendirme Sistemi İlköğretim Programları. http://mufredat.meb.gov.tr/Programlar.aspx adresinden edinilmiştir (Erişim Tarihi: 02.10.2019).

Özgan, H. \& Tekin, A. (2011). Öğrencilerin hazırbulunuşluk düzeylerinin sınıf yönetimine etkisine yönelik öğretmen görüşleri. Mustafa Kemal Üniversitesi Sosyal Bilimler Enstitüsü Dergisi, 8(15), 421 - 434.

Tosuncuoğlu, İ. (2013). İngilizce kelimelerin oyunlarla öğretilmesi. Tarih Kültür ve Sanat Araştırmaları Dergisi, 2(4), 140-146.

UNESCO. (2005). Learning to do: Values for learning and working together in a globalized world (Eds., L.R. Quisumbing \& J. Leo). Bonn, Germany: UNESCO-UNEVOC. https://files.eric.ed.gov/fulltext/ED495380.pdf (Erişim Tarihi: 21.11.2018).

Uzun, M. \& Köse, A. (2017). Okul öncesi eğitimde değerler eğitiminin uygulanmasına yönelik öğretmen görüşleri. Bayburt Eğitim Fakültesi Dergisi, 12(23), 305-338.

Yeşilyurt, E. (2019). Değerler eğitimine uygunluğu açısından öğretim yöntem ve tekniklerinin incelenmesi: Bir derleme çalışması. Ekev Akademi Dergisi, 23(77), 121-146,

Yeşilyurt E. \& Kurt İ. (2012). Değerleri kazandırmasındaki etkililik açısından resmî ve örtük program ile okul dışı etmenlerin öğrenci görüşleri doğrultusunda değerlendirilmesi. Turkish Studies, 7(4), 3253-3272.

Yıldırım, A. \& Şimşek, H. (2005). Sosyal bilimlerde nitel araştırma yöntemleri (Beşinci baskı). Ankara: Seçkin Yayıncılık. 
Extended Abstract

\section{Tolerance Tendency Scale Form for Adults: The Effect of Educational Games on Students' Acquisition of Value: A Case Study}

Gökhan IZGAR, Corresponding Author, Assistant Professor.

Necmettin Erbakan University, Ereğli Faculty of Education, Konya/Turkey.

g.izgar@hotmail.com

https://orcid.org/0000-0002-6835-9701

Article Type: Research Article

https://doi.org/10.34234/ded.736639

Received Date: 13.05 .2020

Accepted Date: 09.09 .2020

Published Date: 25.12.2020

\section{Introduction}

When the primary school curricula (MEB, 2018) are examined, it is seen that the values included in the curricula are tried to be instilled in students through various activities during the classes. These activities mostly address cognitive learning. For example, Izgar (2017), who examined the curriculum of the Human Rights, Citizenship and Democracy Course, found that there were activities such as reading texts, questions based on reading texts, homework, observations, and discussions in textbooks. Additional activities are needed to support in-class activities in the acquisition of high-level skills such as internalizing the value, transforming it into behavior, and using it in daily life. One of these additional activities is educational games. The main purpose of this study is to examine the effects of educational games, which are designed taking into consideration the values of honesty, friendship, responsibility, patience, equa- 
lity, solidarity and justice included in primary school curricula and associated with course outcomes, on students 'cognitive structures and teachers' opinions.

\section{Method}

This research, in which qualitative research method was used, was designed according to the case study design. In qualitative case studies, factors related to a situation are investigated with a holistic approach and how they affect the relevant situation and how they are affected by the relevant situation are examined (Yıldırım \& Şimşek, 2005).

A total of 69 students studying in grades 2, 3 and 4 in a state primary school in the Ereğli district of the Konya province in the 2019-2020 academic year and 3 class teachers constitute the sample of this research.

Word association test was used as the first data collection tool in the study. The word association test is an alternative assessment and evaluation tool that reveals the cognitive structure of an individual about any subject or phenomenon, the links between the concepts in this structure, and whether the relationships between the concepts in their long-term memory are sufficient or meaningful (Bahar, Johnstone \& Sutcliffe, 1999). The semi-structured interview form was used as the second data collection tool in the study. Through the interview form, it was aimed to reveal the effects of educational games on students, and on teachers' opinions about these games.

In the analysis of the word association test, words were classified. Whether the classified words were related to the relevant value was determined. Words associated with the relevant value were analyzed. The frequency of each word associated with the value was revealed. Frequency tables related to the relevant values were created (Bahar, Johnstone \& Sutcliffe, 1999).

Educational games were designed about the values included in the research. The games were designed according to the principle of suitability to the child, taking into account the developmental stages of the students; according to the principle of activity, taking into account the students' learning by doing and experiencing; according to the principle of closeness to life, taking into account the association of games with life; and according to the principle of integrity, taking into account cognitive, affective and kinesthetic learning areas. Educational games were completed within a period of 7 weeks. 


\section{Findings}

The following results were obtained from the analysis of the word association test applied to the students before and after the educational games. After the application, it was observed that the total number of words and frequency values associated with the values of honesty, friendship, patience, equality, solidarity and justice increased at the 2 nd grade level. It was observed that the total number of words and frequencies associated with the values of honesty, friendship, responsibility, solidarity and justice increased at the 3rd grade level. It was observed that the total number of words and frequencies associated with the values of honesty, friendship, patience and equality increased at the 4th grade level.

Although there was a small decrease in the total number of words associated with the values of responsibility at 2 nd grade level, patience and equality at the 3rd grade level, and justice at the 4th grade level after the application, an increase was observed in the frequency values. Despite the fact that there was an increase in the total number of words associated with the values before the application, small decreases were observed in the frequency values.

The following themes were reached in the analysis of the teachers' opinions regarding the effect of educational games on students: Educational games were effective in acquiring values ( $\mathrm{f}=3$ ); the students played educational games with pleasure $(f=3)$; the students were willing to participate in educational games $(f=3)$; I did not experience any difficulties $(f=2)$; the games were generally suited to the grade level $(\mathrm{f}=3)$; some games were below grade level and some above ( $f=1)$; some games could have minor adjustments $(f=2)$.

The following themes were reached in the analysis of the teachers' opinions regarding whether educational games should be included in the curriculum: Educational games should be directly included in the textbooks ( $f=2)$; educational games should be supplementary activities $(\mathrm{f}=1)$.

\section{Discussion, Gonclusions and Suggestions}

Educational games are effective in providing students with the values of honesty, friendship, patience, equality, solidarity and justice at the 2nd grade level; honesty, friendship, responsibility, solidarity and justice at the 3rd grade level, and honesty, friendship, patience and equality at the 4 th grade level. It was concluded that although there was a small decrease in the total number of words regarding 
responsibility in the 2 nd grade, patience and equality in the 3 rd grade, and justice in the 4th grade after the application, an increase was observed in the frequencies. This situation can be interpreted as a positive result in terms of acquisition of values, because there is more repetition of the words associated with the said values at the grade level than before the implementation. In the analysis of the teachers' opinions, results supporting these findings were reached. Namely, teachers pointed out that educational games were effective in acquiring values and should be included directly in the textbooks as a supportive activity, and that students were positively affected by educational games in postapplication value acquisition. There are also studies in the literature that support the findings of the research. Butler (2013) concluded in his research that game-based activities provide significant advantages for teaching social and ethical understanding. In Bolat's (2018) study, it was determined that primary school students found that the educational games were instructive, entertaining, real-life oriented, surprising, creative and taught how to defend rights. In the research of Eliasa (2014), it was concluded that skills such as increasing cooperation and creating greater responsibility among students were gained through games.

On the other hand, although there was an increase in the total number of words as sociated with the values of honesty, responsibility and solidarity at the 4th grade level after the application, it was observed that there were small decreases in the frequencies. This situation can be explained as follows: students may have had difficulty in participating in the educational game related to the value in question, they may have had motivational problems during the application, or they may have not been able to cognitively associate the game with the value in question. There are themes that support this interpretation in the analysis of the teachers' opinions. Namely, the teachers who participated in the study stated that small arrangements could be made in some games and that some games were below the grade level and some above. As a matter of fact, similar results were reached in the research of Biter and Çalışkan (2019). It was observed that the students were bored during the classes due to reasons such as the weakness of the interpretation power of the students selected in the games, the problems related to the planning of time and the participation of a limited number of students.

Another striking finding is that the total word count and/or frequencies of the 3rd grade are higher than those of the 4th grade both before and after the application in all values except for the equality value. The number of students in the 
classes can be shown as the source of this difference for the values of friendship, responsibility and justice. In other words, when the number of students participating in the games related to these values is examined, it is seen that the number of 3 rd grade students is higher. However, for values of honesty, patience and solidarity, this difference cannot be explained by the number of students participating in the games, because the number of students participating in the game is very close to each other. In this case, the readiness levels of students can be indicated as the source of the difference. Therefore, it can be said that the 3rd grade students have more experiences in relation to these values. As a matter of fact, it is known that there may be differences in the readiness levels between the classes in our education system. In Canbulat's (2017) study, which examined the school adaptation and school readiness levels of elementary school students, it was concluded that the readiness levels of the pre-school students were high.

In conclusion, it was observed that educational games designed to provide the values of honesty, friendship, responsibility, patience, equality, solidarity and justice in primary school curriculum positively affected students' cognitive structures in general. In addition, according to the teachers' opinions: It was found that educational games were related to the acquisitions in the curriculum. They gave the students the opportunity to experience these values as concrete life situations. The students were eager to participate in educational games and derived pleasure from them, and there was no difficulty in playing educational games. However, teachers also stated that minor adjustments should be made in the games of these values in order for the second grade students to better understand the values of solidarity and responsibility. Based on this, the following suggestions can be made according to the research findings:

It was tried to provide values of helping and solidarity by using the station technique in the game related to the value of solidarity from among the educational games designed. It may be suggested that the hint-based propositions should be stated in the game instructions so that the second grade students can understand the fine distinction between these two values.

From among the educational games designed, group work was performed in the classroom regarding the value of responsibility. It may be suggested that environments should be created where groups do not affect each other.

In addition to the activities applied in the classes in the acquisition of values, activities that can provide concrete life experiences with such educational games can be included in the primary school curricula. 